\title{
Fluorogenic Probe Using a Mislow-Evans Rearrangement for Real-Time Imaging of Hydrogen Peroxide
}

\author{
Dianne Pham ${ }^{1}$, Upamanyu Basu ${ }^{1}$, Ivanna Pohorilets ${ }^{1}$, Claudette M. St Croix ${ }^{2}$, Simon C. Watkins ${ }^{2}$, and Kazunori Koide ${ }^{1 *}$ \\ ${ }^{1}$ Department of Chemistry, University of Pittsburgh, 219 Parkman Avenue, Pittsburgh, Pennsylvania 15260, United States \\ ${ }^{2}$ Center for Biologic Imaging, Department of Cell Biology, University of Pittsburgh, 3500 Terrace Street, Pittsburgh, \\ Pennsylvania 15261, United States \\ In memory of Professors Kurt Mislow and Hans J. Reich and dedicated to Professor David A. Evans
}

\begin{abstract}
Hydrogen peroxide $\left(\mathrm{H}_{2} \mathrm{O}_{2}\right)$ mediates the biology of wound healing, apoptosis, inflammation, etc. $\mathrm{H}_{2} \mathrm{O}_{2}$ has been fluorometrically imaged with protein- or small molecule-based probes. However, only proteinbased probes have afforded temporal insights within seconds. Small molecule-based electrophilic probes for $\mathrm{H}_{2} \mathrm{O}_{2}$ require many minutes for a sufficient response in biological systems. Here, we report a fluorogenic probe that selectively undergoes a [2,3]-sigmatropic rearrangement (seleno-Mislow-Evans rearrangement) with $\mathrm{H}_{2} \mathrm{O}_{2}$, followed by an acetal hydrolysis, to produce a green fluorescent molecule in seconds. Unlike other electrophilic probes, the current probe acts as a nucleophile. The fast kinetics enabled real-time imaging of $\mathrm{H}_{2} \mathrm{O}_{2}$ produced in endothelial cells in 8 seconds (much earlier than previously shown) and $\mathrm{H}_{2} \mathrm{O}_{2}$ in a zebrafish wound healing model. This work may provide a platform for endogenous $\mathrm{H}_{2} \mathrm{O}_{2}$ detection in real time with chemical probes.
\end{abstract}

Keywords: Fluorescent probe, Oxidation, Selenium, Peroxides, Sigmatropic rearrangement

Hydrogen peroxide $\left(\mathrm{H}_{2} \mathrm{O}_{2}\right)$ is a reactive oxygen species (ROS) involved in many biological processes. As such, misregulation of $\mathrm{H}_{2} \mathrm{O}_{2}$ has been implicated in many diseases. ${ }^{[1]}$ In the cell, $\mathrm{H}_{2} \mathrm{O}_{2}$ is produced along with other ROS in the mitochondria and cytoplasm by the NADPH oxidase family of enzymes, xanthine oxidase, and cytochrome P450 enzymes. ${ }^{[1 \mathrm{a}, 2]}$ In light of the dichotomous nature of $\mathrm{H}_{2} \mathrm{O}_{2}$ in maintaining cellular homeostasis, it has become increasingly important to understand the detailed biology of $\mathrm{H}_{2} \mathrm{O}_{2}{ }^{[1 b, 3]}$

Only recently has the spatiotemporal presence of $\mathrm{H}_{2} \mathrm{O}_{2}$ in wound healing been recognized. ${ }^{[4]}$

Additionally, ROS production is critical for defense against pathogens; however, early studies used nonselective probes for ROS and could not distinguish between effects caused specifically by $\mathrm{H}_{2} \mathrm{O}_{2} \cdot{ }^{[3 a}$, 5] Studies of biological $\mathrm{H}_{2} \mathrm{O}_{2}$ with high specificity and temporal resolution have relied on genetically encoded protein-based probes. ${ }^{[4 a, 6]}$ These studies using protein-based probes have revealed that upon injury to tissue, $\mathrm{H}_{2} \mathrm{O}_{2}$ is produced in seconds to minutes with gradients from the site of injury, facilitating the mobilization of immune cells. ${ }^{[4 a]}$ These results have not been observed using chemical probes, likely due to the comparatively slow reaction kinetics. 


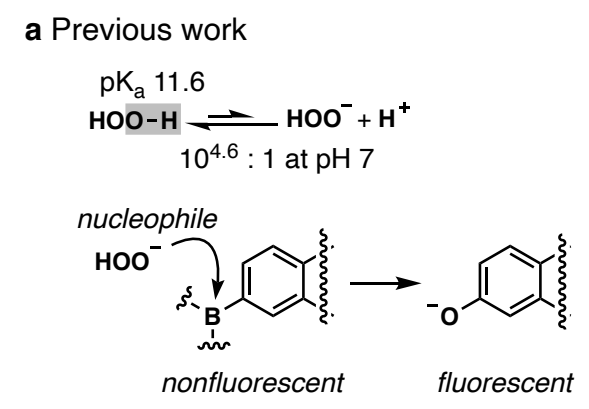

b This work

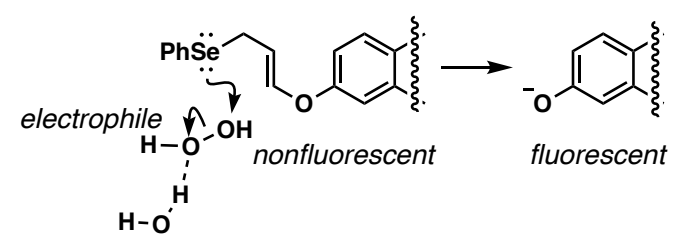

Figure 1. Comparison of (a) boronate-based and (b) selenium-based probes for hydrogen peroxide.

Most chemical probes for $\mathrm{H}_{2} \mathrm{O}_{2}$ have relied on the boronate ester functionality (Figure 1a) for reaction, ${ }^{[7]}$ although other functionalities have been reported. ${ }^{[8]}$ Advances from these studies have allowed for selective detection of $\mathrm{H}_{2} \mathrm{O}_{2}$ over other reactive oxygen and nitrogen species (RNS). This chemistry presumably requires the presence of the hydroperoxide anion, $\mathrm{HOO}^{-}$. Under biological conditions, the abundance of this species should be very low $\left(\sim 0.1 \%\right.$ of $\left.\mathrm{H}_{2} \mathrm{O}_{2}\right)$ because the $\mathrm{pK}_{\mathrm{a}}$ of $\mathrm{H}_{2} \mathrm{O}_{2}$ is 11.6 . When these probes were applied in biological systems, it took ca. $30 \mathrm{~min}$ to produce fluorescence signals. ${ }^{[7 \mathrm{c}, 7 \mathrm{~d}, 7 \mathrm{~g}, 8 \mathrm{e}]}$

To develop a new probe that more rapidly reacts intracellularly, in this study we used the seleno Mislow-Evans rearrangement, which undergoes the oxidation of an allylic selenide with $\mathrm{H}_{2} \mathrm{O}_{2}$ (Figure 1b). ${ }^{[9]}$ This rearrangement is fast even at $0{ }^{\circ} \mathrm{C}^{[10]}$ and requires the neutral and abundant form of $\mathrm{H}_{2} \mathrm{O}_{2}$ to act as an electrophile; this reactivity has not been exploited in the development of probes for $\mathrm{H}_{2} \mathrm{O}_{2}$. We hypothesized that the seleno Mislow-Evans rearrangement would provide a novel platform for the fluorometric detection of $\mathrm{H}_{2} \mathrm{O}_{2}$ with superior kinetics to more favorably compete with the degradation of $\mathrm{H}_{2} \mathrm{O}_{2}$ in cells. Here, we integrate the rearrangement with a spontaneous hydrolysis of the resulting acetal to translate the high reactivity of a selenium atom with $\mathrm{H}_{2} \mathrm{O}_{2}$ into a fluorogenic switch. We present the synthesis of selenide 1 and its selectivity for $\mathrm{H}_{2} \mathrm{O}_{2}$ over other ROS and RNS. We also show that selenide 1 can detect endogenously produced $\mathrm{H}_{2} \mathrm{O}_{2}$ by treatment with ionomycin in macrophages and in a zebrafish wound-healing experiment.

We envisioned that allylic selenide 1 (Figure 2A) could undergo oxidation with $\mathrm{H}_{2} \mathrm{O}_{2}$ through transition state TS1, followed by the Mislow-Evans rearrangement of selenoxide 2 and the subsequent hydrolysis of selenenate $\mathbf{3}$ to form the brightly fluorescent phenol $\mathbf{5}$. For the conversion of $\mathbf{3}$ to $\mathbf{5}$, two pathways are plausible. The first pathway is the nucleophilic cleavage of the Se-O bond of 3 to form hemiacetal 4, which spontaneously forms phenoxide $\mathbf{5}$ and acrolein (Pathway 1). The second is the oxidation of selenenate $\mathbf{3}$ to seleninate $\mathbf{6}$ en route to phenol 5 via hemiacetal 4 (Pathway 2). As shown below, we experimentally determined the actual pathway. 
A
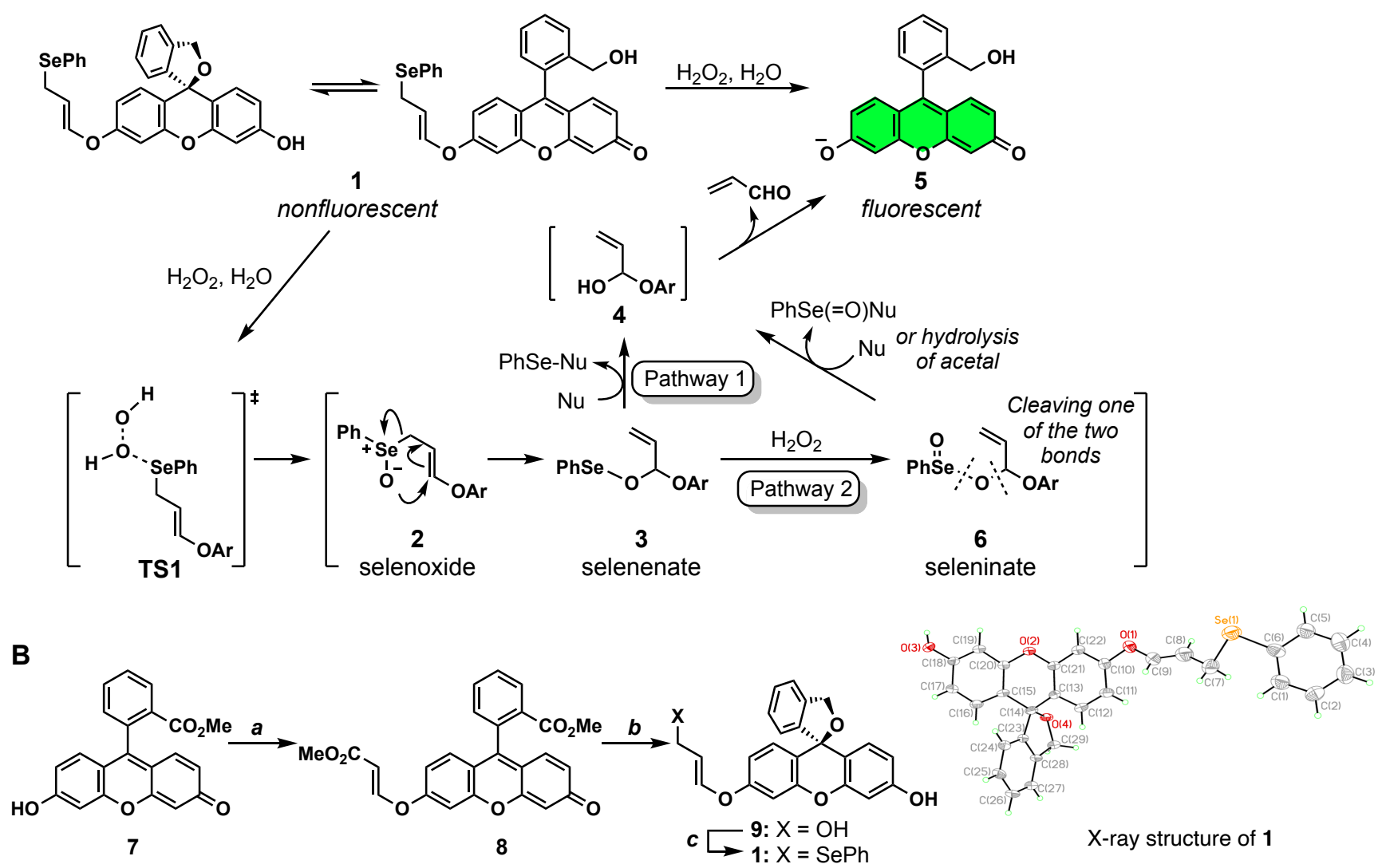

Figure 2. (A) Design of probe 1 based on the seleno-Mislow-Evans rearrangement followed by hydrolysis via two possible pathways. (B) Synthesis of probe 1. Conditions: (a) $\mathrm{N}$-Methylmorpholine (0.3 equiv), methyl propiolate (5.0 equiv), $\mathrm{CH}_{2} \mathrm{Cl}_{2}$, $24 \mathrm{~h}, 79 \%$; (b) DIBALH (7.8 equiv), $\mathrm{CH}_{2} \mathrm{Cl}_{2},-78$ to $23^{\circ} \mathrm{C}, 2 \mathrm{~h}$; then DDQ (1.1 equiv), $\mathrm{Et}_{2} \mathrm{O}, 3 \mathrm{~h}, 0{ }^{\circ} \mathrm{C}, 66 \%$; (c) ${ }^{\mathrm{n}} \mathrm{Bu}_{3} \mathrm{P}(1.2$ equiv), PhSeCN (1.0 equiv), THF, $0^{\circ} \mathrm{C}, 30 \mathrm{~min}, 41 \%$.

The synthesis of selenide 1 (Figure 2B) commenced with the conjugate addition of fluorescein methyl ester 7 to methyl propiolate to afford ester 8 in 79\% yield. The following DIBALH reduction formed alcohol 9 in $66 \%$ yield. The moderate yield was caused by the hydrolysis of the enol ether during aqueous workup. The final Mitsunobu-type reaction ${ }^{[11]}$ afforded selenide 1 in $41 \%$ yield. The structure was confirmed by the X-ray structure analysis. 


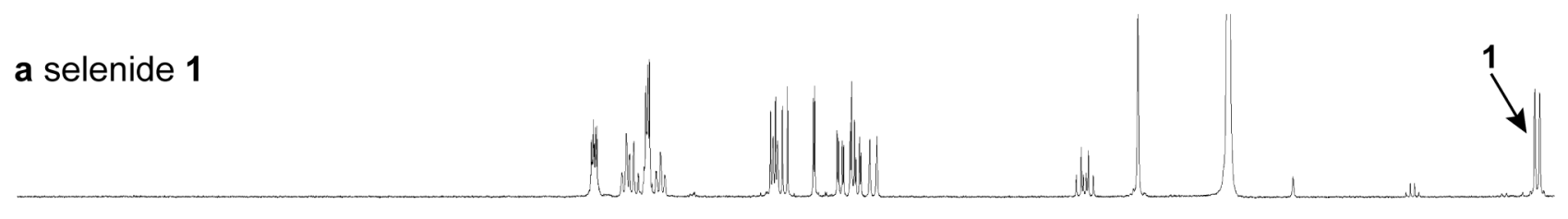

\section{b phenol 5}

c acrolein

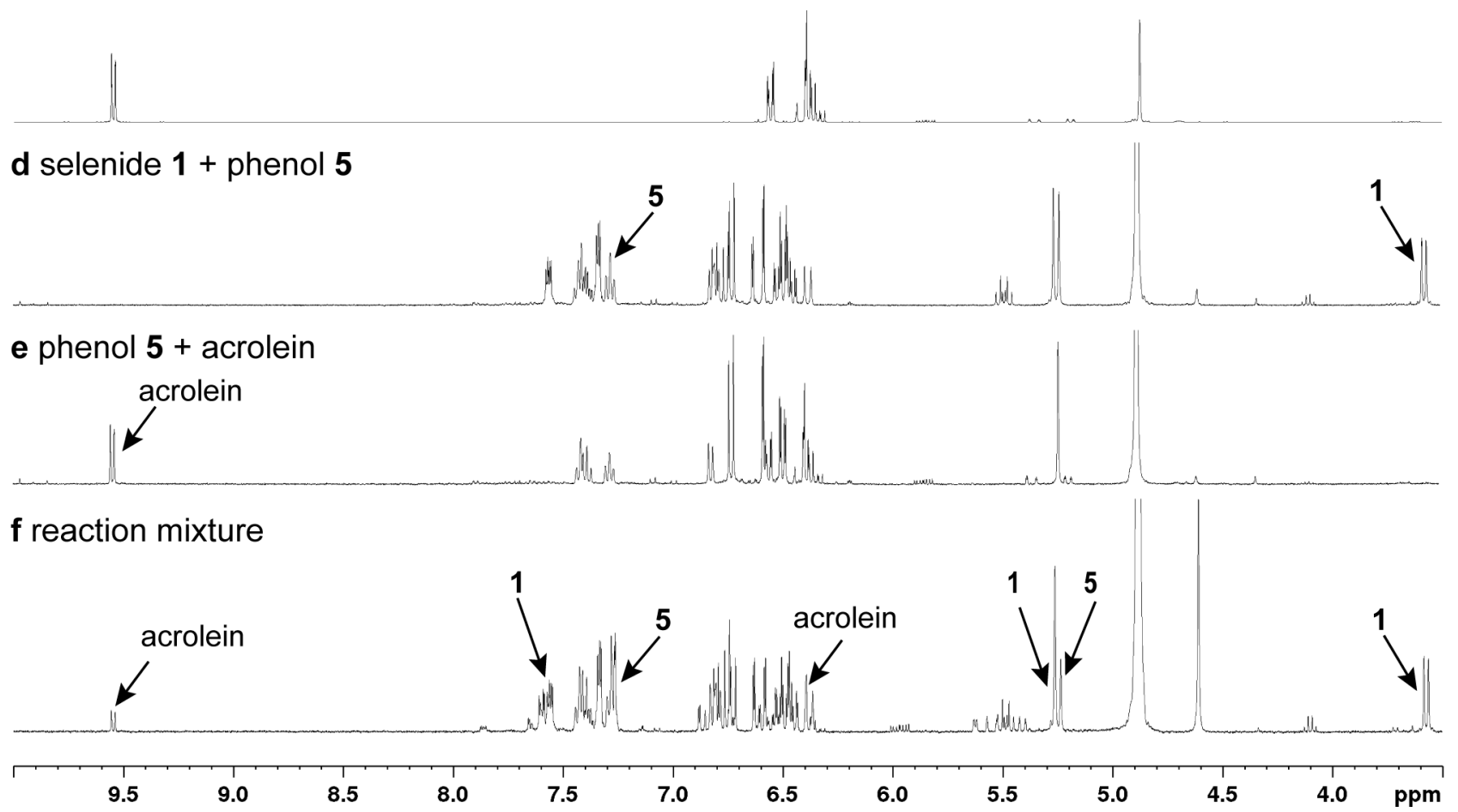

Figure 3. Mechanistic studies ${ }^{1} \mathrm{H}$ NMR (400 MHz, $\mathrm{CD}_{3} \mathrm{OD}$ ) spectra of (a) selenide 1, (b) phenol $\mathbf{5}$, (c), acrolein, (d) selenide 1 and phenol 5 (1:1), (e) acrolein and phenol 5 (1:1), (f) reaction mixture of selenide 1 and $\mathrm{H}_{2} \mathrm{O}_{2}$.

To investigate the mechanism of the reaction between selenide $\mathbf{1}$ and $\mathrm{H}_{2} \mathrm{O}_{2}$ as depicted in Figure $2 \mathrm{~A}$, we monitored the reaction in situ by ${ }^{1} \mathrm{H}$ NMR spectroscopy. Figure 3a-e show selenide 1, phenol 5, acrolein, a 1:1 mixture of $\mathbf{1}$ and 5, and a 1:1 mixture of $\mathbf{5}$ and acrolein in $\mathrm{CD}_{3} \mathrm{OD}$, respectively, Upon treatment of selenide $\mathbf{1}$ with substoichiometric amounts of $\mathrm{H}_{2} \mathrm{O}_{2}$, both phenol $\mathbf{5}$ and acrolein were formed (Figure $3 \mathrm{f}$ ), supporting our proposed design for the $\mathrm{H}_{2} \mathrm{O}_{2}$ detection strategy. The HPLC chromatograms (Figure S1, Supporting Information) revealed that the reaction of selenide 1 with $\mathrm{H}_{2} \mathrm{O}_{2}$ produced phenol $\mathbf{5}$, but did not produce $\mathrm{PhSeO}_{2} \mathrm{H}$. Therefore, pathway 1 (Figure 2A) is operative under these conditions leading to the formation of the putative intermediate $\mathrm{PhSeOH}$ as a side product. 
Since organic selenides are prone to oxidation in air, ${ }^{[12]}$ we investigated the stability of $\mathbf{1}$ under ambient conditions. The ${ }^{1} \mathrm{H}$ NMR analysis of $\mathbf{1}$ in DMSO- $d_{6}$ showed that $\mathbf{1}$ underwent cis-trans isomerization of the enol ether with a half-life of 60 days (Figures S2 and S3, Supporting Information). Even so, the compound was quite resistant to oxidative decomposition up to 60 days as manifested by the presence of only less than $10 \%$ acrolein.

As evident from Figure S4 and Table S1 (Supporting Information), the difference in fluorescence intensity of probe $\mathbf{1}$ and phenol 5, is 27-fold. Generally, $O$-alkylation of Pittsburgh Green suppresses the fluorescence by $200-400$ fold. ${ }^{[13]}$ The somewhat modest fluorescence increase in the current system is attributed to the trace contamination of the fluorescent compound $\mathbf{5}$ during the purification of the non-fluorescent probe $\mathbf{1}$. From the standard calibration curve (Figure S4), the estimated amount of $\mathbf{5}$ in $\mathbf{1}$ as an impurity was calculated to be $2.5 \%$, leading to a 5-10 times higher background signal. Thus, if trace phenol $\mathbf{5}$ can be removed from selenide 1 (HPLC did not improve the purity of 1), the signal increase in the conversion of $\mathbf{5}$ to $\mathbf{1}$ should be $125-$ 250 fold. Nevertheless, the trace amount of $\mathbf{5}$ in $\mathbf{1}$ does not affect the calculation of rate constant shown below (Figure 4).
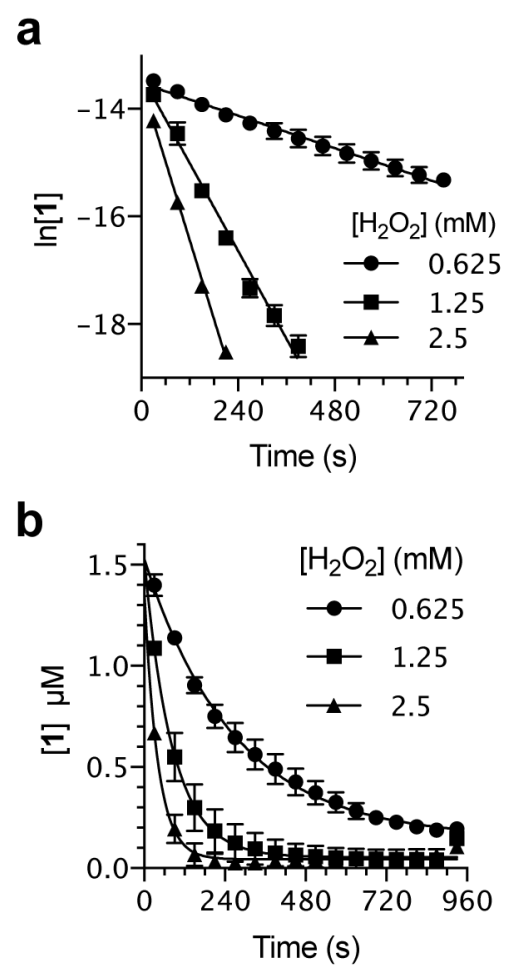

Figure 4. (a) plot of $\ln [1]$ vs $t$ to obtain slope $\left(k^{\prime}\right)$ and (b) plot of [1] vs time. For $(a), Y=-0.002514 X-13.52\left(R^{2}=0.8939\right)$ for $0.625 \mathrm{mM} \mathrm{H}_{2} \mathrm{O}_{2}, \mathrm{Y}=-0.01359 \mathrm{X}-13.38\left(R^{2}=0.9792\right)$ for $1.25 \mathrm{mM} \mathrm{H}_{2} \mathrm{O}_{2}$, and $\mathrm{Y}=-0.02432 \mathrm{X}-13.51\left(R^{2}=0.9978\right)$ for 2.5 $\mathrm{mM} \mathrm{H}_{2} \mathrm{O}_{2}$.

With the fluorometrically measured concentrations of selenide 1 shown in Table S3 (Supporting Information), $\ln [\mathbf{1}]$ versus time (s) was plotted to obtain observed rate constants k' as the slope of the linear plot (Figure 4a). To determine the second-order rate constant of the reaction of 1 with $\mathrm{H}_{2} \mathrm{O}_{2}$, a solution of $\mathbf{1}$ in $5 \%$ 
MeCN in a pH 7.5 HEPES buffer was treated with $\mathrm{H}_{2} \mathrm{O}_{2}$ in a 96-well plate, and the progressive increase in fluorescence was recorded measured every minute until the reaction was completed. The fluorescence readout was converted to the amount of phenol 5 formed using Figure S5. Based on the pseudo first-order kinetic studies (Figure 4b), the second-order rate constant $k$ of the reaction was calculated (details in Supporting Information, Figure S6 and Table S3) to be $9.82 \pm 1.11 \mathrm{M}^{-1} \mathrm{~s}^{-1}$.

To verify that 1 could quantitatively measure $\mathrm{H}_{2} \mathrm{O}_{2}$ concentrations, we incubated 1 with increasing concentrations of $\mathrm{H}_{2} \mathrm{O}_{2}$. Fluorescence increased linearly with $\mathrm{H}_{2} \mathrm{O}_{2}$ concentration (Figure 5a), indicating that the probe could be used to quantify $\mathrm{H}_{2} \mathrm{O}_{2}$.

Following the concentration dependence studies, the selectivity of $\mathbf{1}$ was assessed against $\mathrm{O}_{2}{ }^{\bullet-},{ }^{1} \mathrm{O}_{2}, \cdot \mathrm{OH}$, $\mathrm{ClO}^{-}, \mathrm{ONOO}^{-},{ }^{t} \mathrm{BuOOH}, \mathrm{NO}_{3}{ }^{-}, \mathrm{NO}_{2}{ }^{-}$, and $\mathrm{NO} \cdot$. Relative to $\mathrm{H}_{2} \mathrm{O}_{2}$, little reaction was observed with other ROS and RNS (Figure 5b). The production of some of these ROS required $\mathrm{H}_{2} \mathrm{O}_{2}$ as a reagent or generated $\mathrm{H}_{2} \mathrm{O}_{2}$ as a product, for which we carefully performed control experiments (Supporting Information for details). For example, to determine whether the probe reacts with $\mathrm{O}_{2}{ }^{-}, \mathrm{KO}_{2}$ was added to a solution of 1 buffered at $\mathrm{pH} 7$ for 15 min and compared to the reaction with $\mathrm{H}_{2} \mathrm{O}_{2}$. Since $\mathrm{O}_{2}{ }^{*}$ is known to spontaneously dismutate to form $\mathrm{H}_{2} \mathrm{O}_{2}$, increasing amounts of catalase were added to the samples containing $\mathrm{KO}_{2}$ to ensure that 1 did not react with any of the in-situ-generated $\mathrm{H}_{2} \mathrm{O}_{2}$. Selenide 1 reacted readily with $\mathrm{H}_{2} \mathrm{O}_{2}$, while the observed fluorescence from the samples containing $\mathrm{KO}_{2}$ decreased with increasing catalase concentrations (Figure S7), indicating that 1 did not react with $\mathrm{O}_{2}{ }^{\circ-}$. Therefore, 1 is selective for $\mathrm{H}_{2} \mathrm{O}_{2}$ over $\mathrm{O}_{2}{ }^{\circ-}$.

${ }^{1} \mathrm{O}_{2}$ was formed by the reaction of $\mathrm{Na}_{2} \mathrm{MoO}_{4}$ with $\mathrm{H}_{2} \mathrm{O}_{2} \cdot{ }^{[14]}$ A large fluorescence increase was observed only in the samples containing $100 \mu \mathrm{M}$ of both $\mathrm{Na}_{2} \mathrm{MoO}_{4}$ and $\mathrm{H}_{2} \mathrm{O}_{2}$ (Figure S8). Fluorescence did not increase in samples containing only $\mathrm{Na}_{2} \mathrm{MoO}_{4}$, indicating that the probe was not reacting with the $\mathrm{Na}_{2} \mathrm{MoO}_{4}$. Together, these results suggested that the probe may have reacted with ${ }^{1} \mathrm{O}_{2}$. However, the addition of $\mathrm{NaN}_{3}$, a known ${ }^{1} \mathrm{O}_{2}$ scavenger, ${ }^{[15]}$ did not decrease the fluorescence. Thus, we concluded that the fluorescence increase was caused by the $\mathrm{H}_{2} \mathrm{O}_{2}$ required to produce ${ }^{1} \mathrm{O}_{2}$ and not by ${ }^{1} \mathrm{O}_{2}$ itself $.10^{4} \mathrm{U} / \mathrm{mL}$ catalase was added to the solutions to verify that 1 indeed responded to excess $\mathrm{H}_{2} \mathrm{O}_{2}$ that had not reacted with the $\mathrm{Na}_{2} \mathrm{MoO}_{4}$. The addition of catalase abolished the fluorescence signal observed in the presence of high concentrations of $\mathrm{H}_{2} \mathrm{O}_{2}$ (Figure S8). 
a

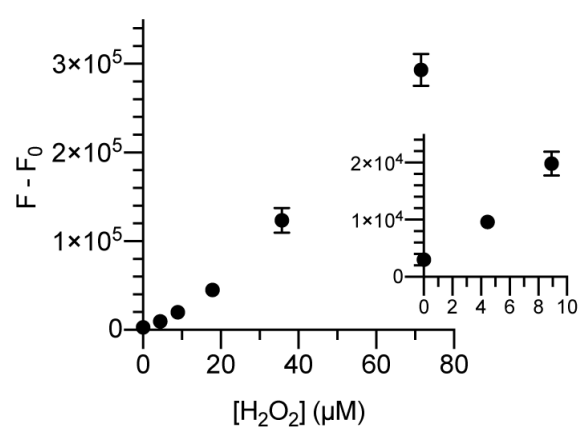

b

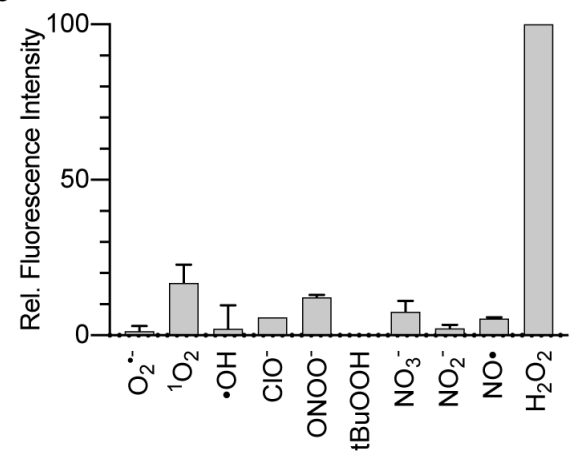

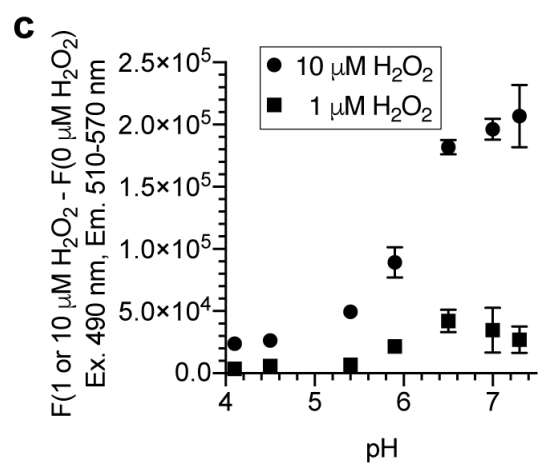

Figure 5. The fluorescence response of $1(1 \mu \mathrm{M})$ at $\mathrm{pH} 7$ (a) with increasing concentrations of $\mathrm{H}_{2} \mathrm{O}_{2}$ or (b) various ROS. (a) $10 \mu \mathrm{M} 1,0-71.5 \mu \mathrm{M} \mathrm{H}_{2} \mathrm{O}_{2}, 14.5: 85.5 \mathrm{MeCN} / 50 \mathrm{mM}$ phosphate $\mathrm{pH}$ 7, (b) Data were normalized so that the reaction of 1 and $\mathrm{H}_{2} \mathrm{O}_{2}$ was set to 100. Excess ROS and RNS compared to 1 was used. (c) The fluorescence response of 1 (10 $\mu M$ ) with $\mathrm{H}_{2} \mathrm{O}_{2}$ $(0,1$, or $10 \mu \mathrm{M})$ at various pHs. $10 \mu \mathrm{M} \mathrm{1}, 1: 9 \mathrm{MeOH} / 25 \mathrm{mM}$ phosphate in water, $20 \mathrm{~min}$. The $y$-axis shows (fluorescence intensity with 1 or $10 \mu \mathrm{M} \mathrm{H}_{2} \mathrm{O}_{2}$ ) - (fluorescence intensity with no $\mathrm{H}_{2} \mathrm{O}_{2}$ ).

The reactivity of $\mathbf{1}$ with $\cdot \mathrm{OH}$ was also investigated. $\cdot \mathrm{OH}$ was generated from the reaction of $\mathrm{Fe}^{2+}$ with $\mathrm{H}_{2} \mathrm{O}_{2}{ }^{[16]}$ A solution of $\mathbf{1}$ was titrated with $\mathrm{FeSO}_{4}$ and $\mathrm{H}_{2} \mathrm{O}_{2}$. Fluorescence did not increase as the concentration of $\mathrm{FeSO}_{4}$ increased (Figure S9), indicating that neither $\mathrm{FeSO}_{4}$ nor the $\cdot \mathrm{OH}$ reacted with the probe. Addition of catalase to the solution reduced fluorescence intensity, indicating that the enhanced signals were caused by the reaction of the probe with the $\mathrm{H}_{2} \mathrm{O}_{2}$ required to produce $\bullet \mathrm{OH}$.

Next, we tested whether $\mathrm{OCl}^{-}, \mathrm{ONOO}^{-}$(peroxynitrite), and ${ }^{t} \mathrm{BuOOH}$ would react with $\mathbf{1}$. No statistically significant increase in fluorescence intensity was observed with increasing concentrations of $\mathrm{OCl}^{-}$. A slight increase in fluorescence intensity was observed with increasing $\mathrm{ONOO}^{-}$concentration (Figure S10). This may be attributed to trace amounts of $\mathrm{H}_{2} \mathrm{O}_{2}$ in the $\mathrm{ONOO}^{-}$solution. ${ }^{[17]}$ Furthermore, ONOO- may be too unstable to last and react with 1 under aqueous conditions because, once protonated, has only a half-life of $1.9 \mathrm{~s}$ at $\mathrm{pH}$ 7.4. ${ }^{[18]}{ }^{t} \mathrm{BuOOH}$ did not produce fluorescence even at $10 \mu \mathrm{M}$ (Figure S11). The minute or negligible fluorescence signals observed in these studies led us to conclude that the tested ROS do not interfere with the 1based fluorometric method for $\mathrm{H}_{2} \mathrm{O}_{2}$.

We then sought to determine whether RNS would react with 1 to produce fluorescence. The probe was exposed to either $\mathrm{NO}_{2}{ }^{-}, \mathrm{NO}_{3}{ }^{-}$(nitrate), or $\mathrm{NO} \bullet$ at various concentrations. The fluorescence change over the first 15 min was reported for $\mathrm{NO}_{2}{ }^{-}$and $\mathrm{NO}_{3}{ }^{-}$in Figure S12 and S13, respectively. No concentration dependence was observed with either $\mathrm{NO}_{2}{ }^{-}$or $\mathrm{NO}_{3}{ }^{-}$indicating that $\mathbf{1}$ did not react with these RNS. Similar results were obtained for $\mathrm{NO} \bullet$ (Figure S14). These data suggest that 1 did not react with $\mathrm{NO}_{2}{ }^{-}, \mathrm{NO}_{3}{ }^{-}$, nor $\mathrm{NO} \cdot$. Altogether, the fluorometric method is selective for $\mathrm{H}_{2} \mathrm{O}_{2}$.

We studied the probe's response to $\mathrm{H}_{2} \mathrm{O}_{2}$ in the $\mathrm{pH}$ 4-7.3 range to determine whether this technology would work in acidic and neutral intracellular environments, such as lysosomes (pH 5), ${ }^{[19]}$ Golgi apparatus (pH 6.4-6.8), ${ }^{[20]}$ mitochondria (pH 6.9-8.0), ${ }^{[20]}$ and cytoplasm (pH 7.1-7.6). ${ }^{[20]}$ The probe should ideally also work 
under oxidative stress conditions, wherein $\mathrm{pH}$ decreases to $6.9-7.0 .^{[21]}$ We found that the fluorescence signals were higher when the $\mathrm{pH}$ was above 5.4 (Figure 5c). The lower signals under acidic conditions match the $\mathrm{pH}-$ fluorescence profile of phenol $\mathbf{5}$ (Figure S15) and are not related to efficiency of the conversion from $\mathbf{1}$ to $\mathbf{5}$. Therefore, the fluorescence method is effective in most of the biologically relevant $\mathrm{pH}$ range.

We then attempted to image $\mathrm{H}_{2} \mathrm{O}_{2}$ within cells. HeLa cells were incubated with $0.5 \mu \mathrm{M} 1$ for 15 min prior to imaging. After washing with HBSS and replacing the media, $\mathrm{H}_{2} \mathrm{O}_{2}$ was added. Within $30 \mathrm{~s}$, a significant increase in fluorescence was observed in HeLa cells (Figure 6a). Punctate fluorescence in cytoplasm suggested that 1 might localize within mitochondria.

After detecting exogenously added $\mathrm{H}_{2} \mathrm{O}_{2}$ in cells, we focused our studies on more biologically relevant, endogenous $\mathrm{H}_{2} \mathrm{O}_{2}$. We attempted to monitor endogenous $\mathrm{H}_{2} \mathrm{O}_{2}$ production upon stimulation with ionomycin in RAW cells. ${ }^{[22]}$ When ionomycin was added in the presence of the most widely used fluorescent probe for ROS, dihydrodichlorofluorescein acetate, fluorescence increase could hardly be observed (Figure S16). In contrast, with probe 1, a significant response was observed within $30 \mathrm{~s}$ of addition of ionomycin relative to the baseline fluorescence (Figure $6 \mathrm{~b}$ and Figure $6 \mathrm{c}$ ) and peaked at $48 \mathrm{~s}$. Therefore, not only did this experiment show the superiority with probe $\mathbf{1}$, the kinetics of pharmacological $\mathrm{H}_{2} \mathrm{O}_{2}$ production was found to be much faster than previously thought. ${ }^{[23]}$

To study the localization of $\mathbf{1}$, endothelial cells were simultaneously treated with $\mathbf{1}$ and MitoTracker Red for $20 \mathrm{~min}$ (Figure 6d). The first image taken $8 \mathrm{~s}$ after the addition of ionomycin already showed increased fluorescence, and time-lapse imaging showed that fluorescence continued to increase over time. The overlap of the green and red fluorescence indicated that the probe might be localizing to mitochondria. However, the Pearson correlation coefficient was $0.114 \pm 0.034$, suggesting that although some overlap with mitochondria was observed, the bulk of the green fluorescence was observed outside of mitochondria. Furthermore, the diffusion of both the green and red fluorescence indicated that stimulation with ionomycin likely induced changes in mitochondrial membrane potential or permeability causing the contents to leak out. 


\section{a}
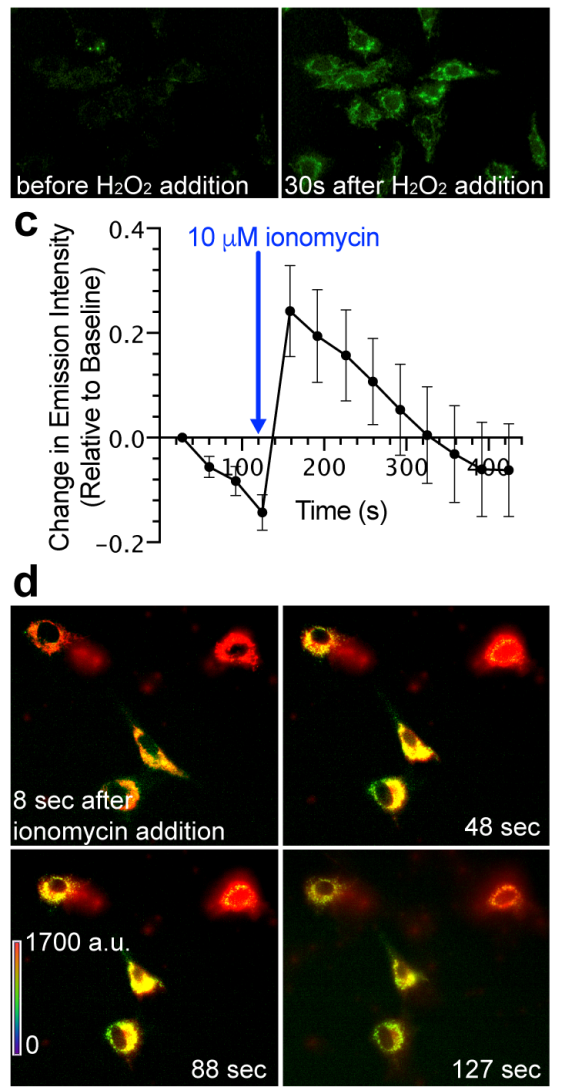

b

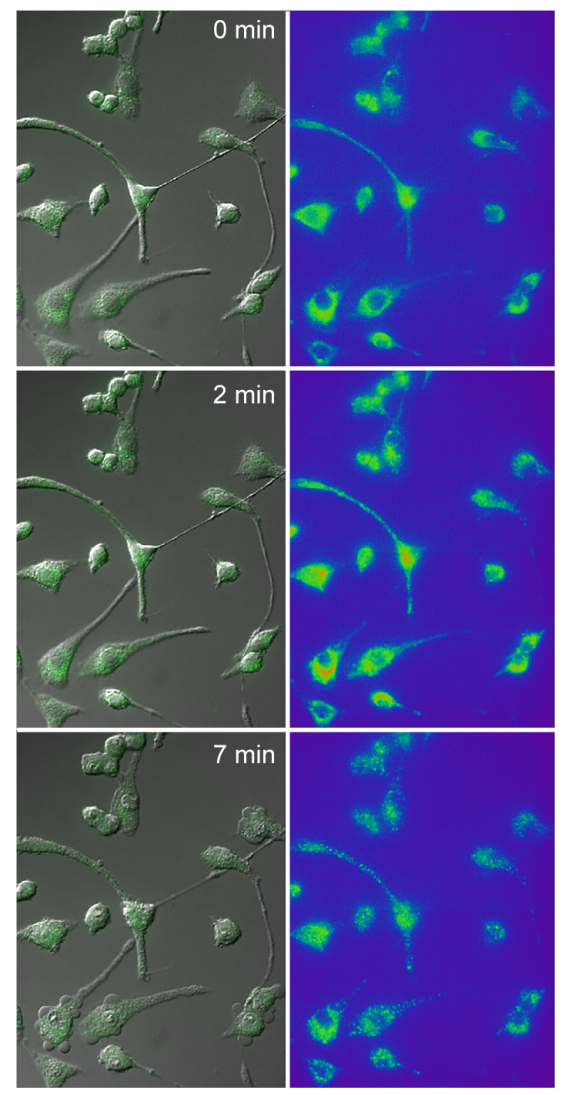

Figure 6. Cellular images using 1. (a) HeLa cells treated with 1 showed a significant fluorescence increase after the addition of $\mathrm{H}_{2} \mathrm{O}_{2}$. Cells were loaded with 1 for 15 min and washed prior to imaging. $\mathrm{H}_{2} \mathrm{O}_{2}$ was added while imaging. (b) RAW macrophages loaded with $0.5 \mu \mathrm{M} 1$ showed (c) a significant response within $30 \mathrm{~s}$ of addition of ionomycin (final concentration: $10 \mu \mathrm{M}$ ). Fluorescence channel (green) and pseudo-color shown. (d) Endothelial cells loaded with 1 and MitoTracker Red were stimulated with ionomycin (final concentration: $10 \mu \mathrm{M}$ ). Colocalization studies revealed mildly increased green fluorescence intensity in mitochondria.

$\mathrm{H}_{2} \mathrm{O}_{2}$ has been recognized as a critical signaling molecule for the recruitment of immune cells for wound regeneration. ${ }^{[4]}$ To date, only genetically encoded protein-based fluorescent probes have been able to illuminate the spatiotemporal dynamics of $\mathrm{H}_{2} \mathrm{O}_{2}$ for wound healing models in zebrafish. ${ }^{[4]}$ We hypothesized that our method might be rapid enough to match the protein-based imaging in vivo. As a platform to test this hypothesis, we applied 1 to image a zebrafish tail wound-healing model. Fish were loaded with probe $\mathbf{1}$ for $2 \mathrm{~h}$ before anesthetizing and mounting them in agarose. The tail fin was subsequently snipped, and the images were taken every $60 \mathrm{~s}$. We observed an increase in fluorescence intensity, with the fluorescence at a maximum approximately 10-20 min after tail snipping. As shown in Figure 7 and the movie in the Supporting Information, the probe was capable of providing the spatiotemporal information that matches the previous report. ${ }^{[4]}$ 

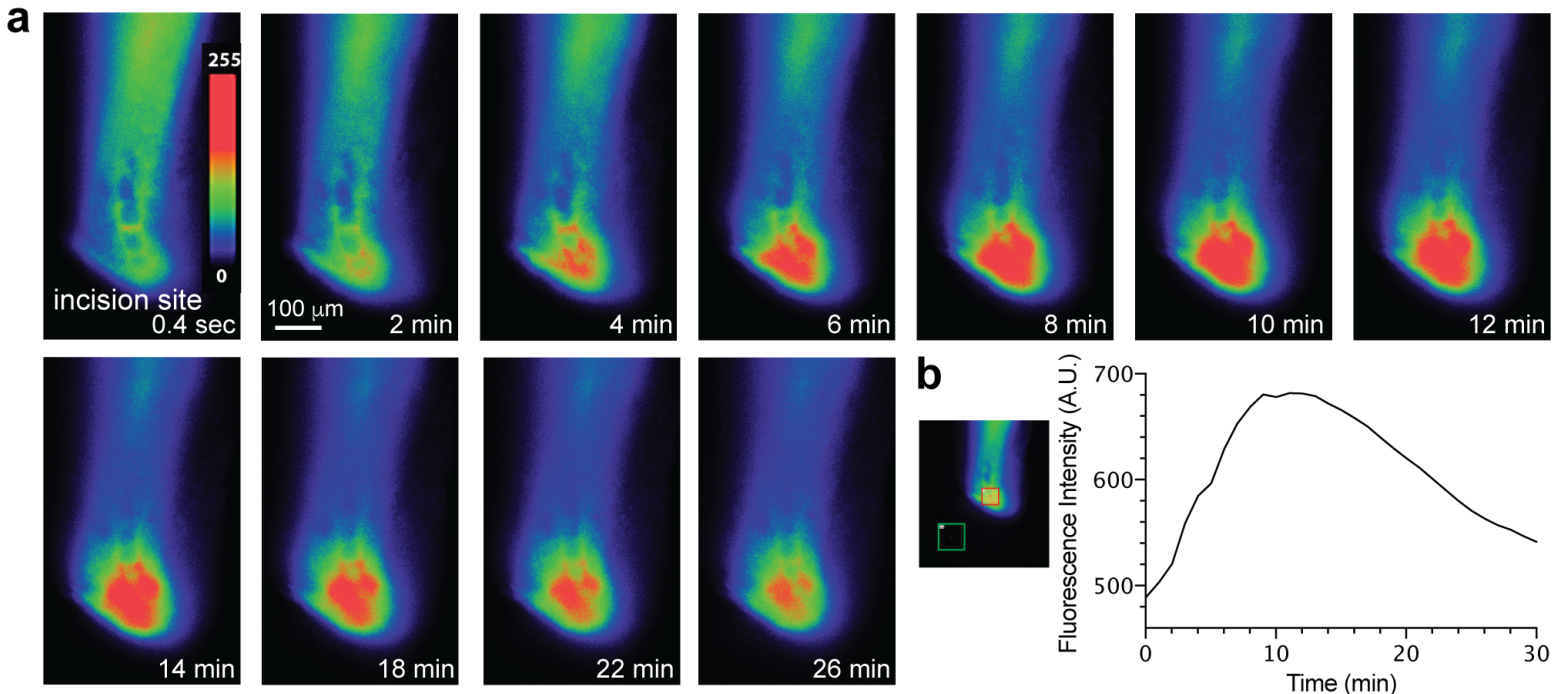

Figure 7. Imaging of $\mathrm{H}_{2} \mathrm{O}_{2}$ in zebrafish wound-healing model. (a) Snap shots of the fluorescence imaging of wound-induced $\mathrm{H}_{2} \mathrm{O}_{2}$. Zebrafish were loaded with 1 , then had the tails snipped. $\mathrm{H}_{2} \mathrm{O}_{2}$ was produced at the incision site over the course of 30 min. The original movies are available in the Supporting Information. (b) The fluorescence intensity over time. The $\mathrm{Y}$-axis = fluorescence intensity in the red square - fluorescence intensity in the green square.

In conclusion, the reaction of the nonfluorescent selenide 1 with $\mathrm{H}_{2} \mathrm{O}_{2}$ forms the fluorescent phenol $\mathbf{5}$ via the oxidation/[2,3]-sigmatropic rearrangement/hydrolysis sequence. Selenide 1 reacts with $\mathrm{H}_{2} \mathrm{O}_{2}$ seven times faster than boronate-based probes. The second-order rate constant for the reaction of 1 with $\mathrm{H}_{2} \mathrm{O}_{2}$ was of the same order of magnitude as the reaction of thiols with $\mathrm{H}_{2} \mathrm{O}_{2}$, indicating that the detection of intracellular $\mathrm{H}_{2} \mathrm{O}_{2}$ is not severely hampered by endogenous thiols. This is consistent with the notion that the oxidation of selenium is faster than that of sulfur compounds. ${ }^{[24]}$ Our careful control experiments ensured that we were monitoring the intended ROS. Selenide 1 was found to be selective for $\mathrm{H}_{2} \mathrm{O}_{2}$.

Selenide 1 instantaneously responded to both exogenously applied and endogenously produced $\mathrm{H}_{2} \mathrm{O}_{2}$, indicating its applicability in gaining spatiotemporal insights into cellular pathways involving $\mathrm{H}_{2} \mathrm{O}_{2}$. Ionomycin is a widely used reagent to intracellularly induce $\mathrm{H}_{2} \mathrm{O}_{2}$ in approximately 2 min. ${ }^{[23]}$ We discovered that $\mathrm{H}_{2} \mathrm{O}_{2}$ was produced earlier (8-48 s) with ionomycin. Generally, chemical probes for $\mathrm{H}_{2} \mathrm{O}_{2}$ detect endogenously produced $\mathrm{H}_{2} \mathrm{O}_{2}$ later times (ca. $30 \mathrm{~min}$ ). ${ }^{[7 \mathrm{c}, 7 \mathrm{~d}, 7 \mathrm{~g}, 8 \mathrm{e}]}$ In the zebrafish tail wounding model, we observed the rapid generation of $\mathrm{H}_{2} \mathrm{O}_{2}$ near the wound site in real time using selenide 1, recapitulating the results using a protein-based probe. ${ }^{[4 a]}$

We acknowledge that two challenges exist with 1. First, the fluorophore 5 diffuses throughout the cell, complicating studies that require extended time periods. Second, the $\mathrm{pK}_{\mathrm{a}}$ of $\mathbf{5}$ is $\sim 7$ and thus the fluorescence signals are weakened under acidic conditions. Nonetheless, the use of seleno Mislow-Evans rearrangement may provide a new platform for fluorometric detection of intracellular $\mathrm{H}_{2} \mathrm{O}_{2}$.

\section{Acknowledgements}


This work was funded by US National Science Foundation Grants CHE-0911092 and CHE-1506942. We thank

Dr. Steve Geib (University of Pittsburgh) for the X-ray analysis of $\mathbf{1}$ and Mr. Jevin M. Jupena (University of

Pittsburgh) for the re-synthesis of probe 1.

[1] (a) C. C. Winterbourn, Nat. Chem. Biol. 2008, 4, 278-286; (b) H. Sies, D. P. Jones, Nat. Rev. Mol. Cell Biol. 2020, 10.1038/s41580-020-0230-3.

[2] J. R. Stone, S. Yang, Antioxid. Redox Signaling 2006, 8, 243-270.

[3] (a) J. B. Bliska, D. S. Black, Infect. Immun. 1995, 63, 681-685; (b) K. M. Holmström, T. Finkel, Nat. Rev. Mol. Cell Biol. 2014, 15, 411-421; (c) F. Antunes, P. M. Brito, Redox Biol. 2017, 13, 1-7; (d) É. Dóka, T. Ida, M. Dagnell, Y. Abiko, N. C. Luong, N. Balog, T. Takata, B. Espinosa, A. Nishimura, Q. Cheng, Y. Funato, H. Miki, J. M. Fukuto, J. R. Prigge, E. E. Schmidt, E. S. J. Arnér, Y. Kumagai, T. Akaike, P. Nagy, Sci. Adv. 2020, 6, eaax8358; (e) S. F. Erttmann, N. O. Gekara, Nat. Commun. 2019, 10, 3493; (f) J.-F. Pei, X.-K. Li, W.-Q. Li, Q. Gao, Y. Zhang, X.-M. Wang, J.-Q. Fu, S.-S. Cui, J.-H. Qu, X. Zhao, D.-L. Hao, D. Ju, N. Liu, K. S. Carroll, J. Yang, E. E. Zhang, J.-M. Cao, H.-Z. Chen, D.-P. Liu, Nat. Cell Biol. 2019, 21, 1553-1564; (g) W. Qian, N. Kumar, V. Roginskaya, E. Fouquerel, P. L. Opresko, S. Shiva, S. C. Watkins, D. Kolodieznyi, M. P. Bruchez, B. Van Houten, Proc. Natl. Acad. Sci. U. S. A. 2019, 116, 18435-18444.

[4] (a) P. Niethammer, C. Grabher, A. T. Look, T. J. Mitchison, Nature 2009, 459, 996-999; (b) J. Pillay, V. M. Kamp, E. van Hoffen, T. Visser, T. Tak, J. W. Lammers, L. H. Ulfman, L. P. Leenen, P. Pickkers, L. Koenderman, J. Clin. Invest. 2012, 122, 327-336; (c) B. Enyedi, P. Niethammer, Methods Enzymol. 2013, 528, 237-255; (d) P. Martin, R. Nunan, Brit. J. Dermatol. 2015, 173, 370-378; (e) C. Dunnill, T. Patton, J. Brennan, J. Barrett, M. Dryden, J. Cooke, D. Leaper, N. T. Georgopoulos, Int. Wound J. 2017, 14, 89-96; (f) M. Jelcic, B. Enyedi, J. B. Xavier, P. Niethammer, Biophys. J. 2017, 112, 2011-2018; (g) B. Kunkemoeller, T. R. Kyriakides, Antioxid. Redox Signaling 2017, 27, 823-838; (h) A. Hervera, F. De Virgiliis, I. Palmisano, L. Zhou, E. Tantardini, G. Kong, T. Hutson, M. C. Danzi, R. B.-T. Perry, C. X. C. Santos, A. N. Kapustin, R. A. Fleck, J. A. Del Río, T. Carroll, V. Lemmon, J. L. Bixby, A. M. Shah, M. Fainzilber, S. Di Giovanni, Nat. Cell Biol. 2018, 20, 307-319; (i) P. Niethammer, Semin. Cell Dev. Biol. 2018, 80, 13-16; (j) M. M. G. Romero, G. McCathie, P. Jankun, H. H. Roehl, Nat. Commun. 2018, 9, 4010; (k) J. Chen, T. Yu, X. He, Y. Fu, L. Dai, B. Wang, Y. Wu, J. He, Y. Li, F. Zhang, J. Zhao, C. Liu, Biochem. Biophys. Res. Commun. 2019, 516, 680-685.

[5] (a) O. Myhre, J. M. Andersen, H. Aarnes, F. Fonnum, Biochem. Pharmacol. 2003, 65, 1575-1582; (b) M. M. Tarpey, I. Fridovich, Circ. Res. 2001, 89, 224-236; (c) A. Levine, R. Tenhaken, R. Dixon, C. Lamb, Cell 1994, 79, 583-593.

[6] K. N. Markvicheva, D. S. Bilan, N. M. Mishina, A. Y. Gorokhovatsky, L. M. Vinokurov, S. Lukyanov, V. V. Belousov, Bioorg. Med. Chem. 2011, 19, 1079-1084.

[7] (a) M. C. Y. Chang, A. Pralle, E. Y. Isacoff, C. J. Chang, J. Am. Chem. Soc. 2004, 126, 15392-15393; (b) B. C. Dickinson, Y. Tang, Z. Y. Chang, C. J. Chang, Chem. Biol. 2011, 18, 943-948; (c) U. Rodella, M. Scorzeto, E. Duregotti, S. Negro, B. C. Dickinson, C. J. Chang, N. Yuki, M. Rigoni, C. Montecucco, Neurobiol. Dis. 2016, 96, 95-104; (d) Y. Lu, X. Shi, W. Fan, C. A. Black, Z. Lu, C. Fan, Spectrochim. Acta, Part A 2018, 190, 353-359; (e) H. Wang, Z. X. He, Y. Y. Yang, J. Zhang, W. Zhang, W. Zhang, P. Li, B. Tang, Chem. Sci. 2019, 10, 10876-10880; (f) J. Pallu, C. Rabin, G. Creste, M. Branca, F. Mavre, B. Limoges, Chem.-Eur. J. 2019, 25, 7534-7546; (g) P. Hou, S. Chen, G. Liang, H. Li, H. Zhang, Spectrochim. Acta, Part A 2020, 236, 118338.

[8] (a) M. Abo, Y. Urano, K. Hanaoka, T. Terai, T. Komatsu, T. Nagano, J. Am. Chem. Soc. 2011, 133, 10629-10637; (b) A. P. Singh, K. M. Lee, D. P. Murale, T. Jun, H. Liew, Y. H. Suh, D. G. Churchill, Chem. Commun. 2012, 48, 7298-7300; (c) S. T. Manjare, Y. Kim, D. G. Churchill, Acc. Chem. Res. 2014, 47, 2985-2998; (d) Z. Lou, P. Li, K. Han, Acc. Chem. Res. 2015, 48, 1358-1368; (e) S. Ye, J. J. Hu, D. Yang, Angew. Chem., Int. Ed. 2018, 57, 10173-10177; (f) B. Li, J.-B. Chen, Y. Xiong, X. Yang, C. Zhao, J. Sun, Sens. Actuators, B 2018, 268, 475-484; (g) D.-J. Zheng, Y.-S. Yang, H.-L. Zhu, Trends Anal. Chem. 2019, 118, 625-651.

[9] (a) P. Bickart, F. W. Carson, J. Jacobus, E. G. Miller, K. Mislow, J. Am. Chem. Soc. 1968, 90, 4869-4876; (b) D. A. Evans, G. C. Andrews, Acc. Chem. Res. 1974, 7, 147-155; (c) H. J. Reich, J. Org. Chem. 1975, 40, 2570-2572.

[10] B. J. Albert, A. Sivaramakrishnan, T. Naka, N. L. Czaicki, K. Koide, J. Am. Chem. Soc. 2007, 129, $2648-2659$.

[11] P. A. Grieco, S. Gilman, M. Nishizawa, J. Org. Chem. 1976, 41, 1485-1486.

[12] A. Krief, F. Lonez, Tetrahedron Lett. 2002, 43, 6255-6257.

[13] S. Ando, K. Koide, J. Am. Chem. Soc. 2011, 133, 2556-2566.

[14] G. Chen, F. Song, J. Wang, Z. Yang, S. Sun, J. Fan, X. Qiang, X. Wang, B. Dou, X. Peng, Chem. Commun. 2012, 48, 29492951.

[15] (a) K. Yamada, T. Ono, H. Nishioka, J. Radiat. Res. 1996, 37, 29-37; (b) M. Osada, Y. Ogura, H. Yasui, H. Sakurai, Biochem. Biophys. Res. Commun. 1999, 263, 392-397.

[16] E. W. Miller, A. E. Albers, A. Pralle, E. Y. Isacoff, C. J. Chang, J. Am. Chem. Soc. 2005, 127, 16652-16659.

[17] G. Merényi, J. Lind, G. Czapski, S. Goldstein, Proc. Natl. Acad. Sci. U. S. A. 2000, 97, 8216-8218.

[18] J. S. Beckman, T. W. Beckman, J. Chen, P. A. Marshall, B. A. Freeman, Proc. Natl. Acad. Sci. U. S. A. 1990, 87, $1620-1624$.

[19] S.-S. Li, M. Zhang, J.-H. Wang, F. Yang, B. Kang, J.-J. Xu, H.-Y. Chen, Anal. Chem. 2019, 91, 8398-8405.

[20] J. Llopis, J. M. McCaffery, A. Miyawaki, M. G. Farquhar, R. Y. Tsien, Proc. Natl. Acad. Sci. U. S. A. 1998, 95, 6803-6808.

[21] W. Shi, X. Li, H. Ma, Angew. Chem., Int. Ed. 2012, 51, 6432-6435.

[22] E. J. Swindle, J. A. Hunt, J. W. Coleman, J. Immunol. 2002, 169, 5866-5873.

[23] C. Dahlgren, A. Johansson, K. Orselius, Biochimica et Biophysica Acta 1989, 1010, 41-48. 
[24] Advanced Organic Chemistry: Reaction Mechanisms By Reinhard Bruckner, 1st edition, Page 573 Chapter 14

\section{Table of Content figure}

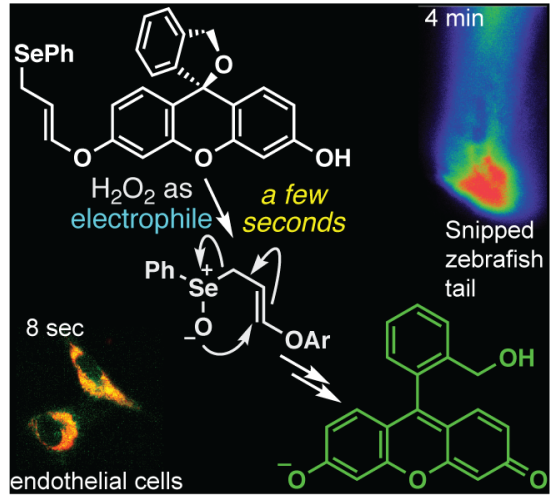




\section{Table of Contents}

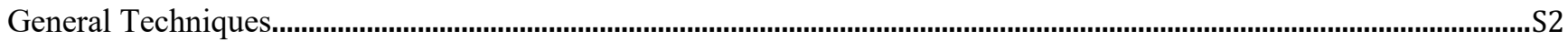

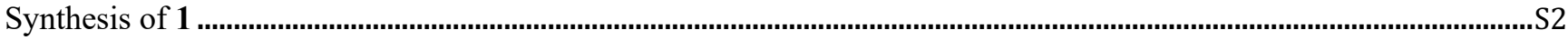

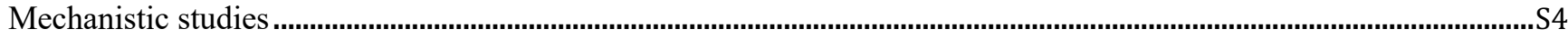

HPLC chromatogram of selenide 1 and phenol 5

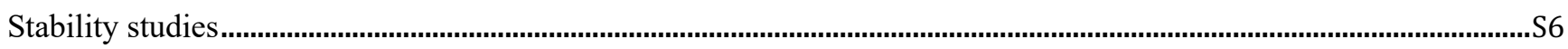

Determination of the difference in fluorescence intensity between selenide $\mathbf{1}$ and phenol $\mathbf{5}$..........................................S7

Pseudo first order kinetics and evaluation of second order rate constant ......................................................................

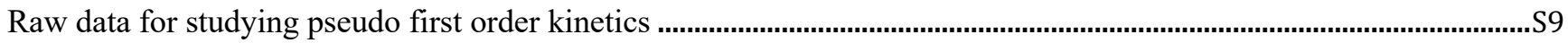

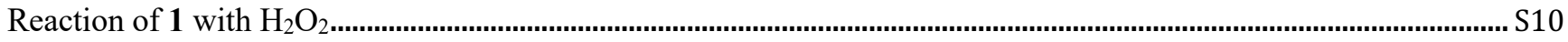

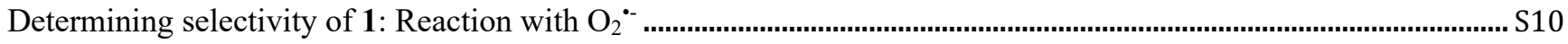

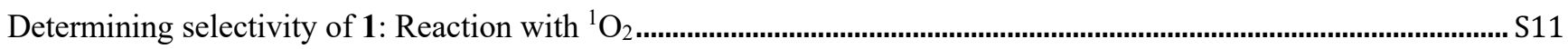

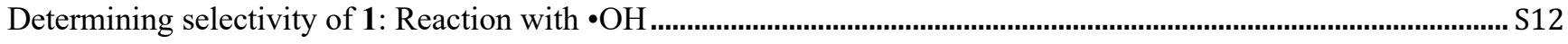

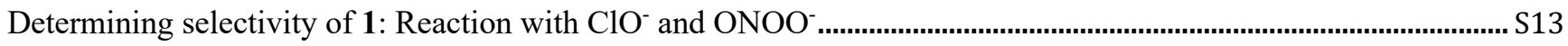

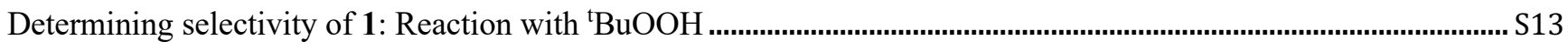

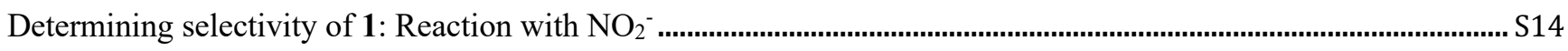

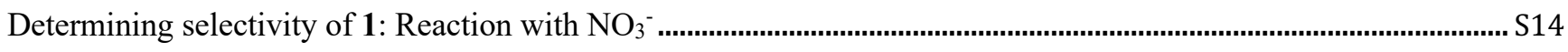

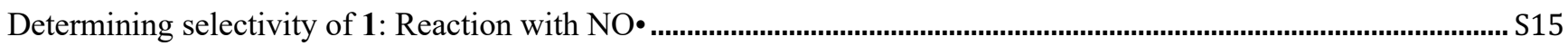

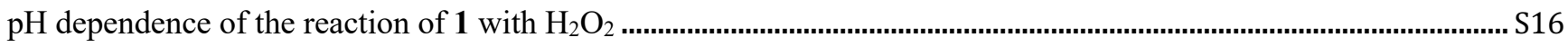

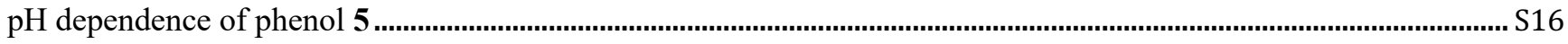

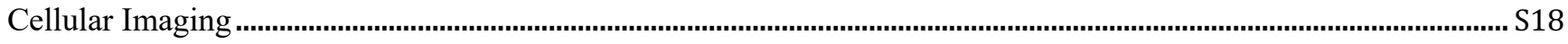

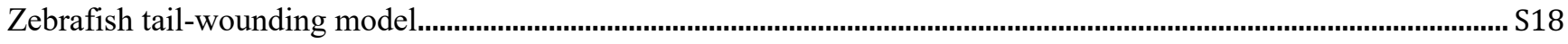

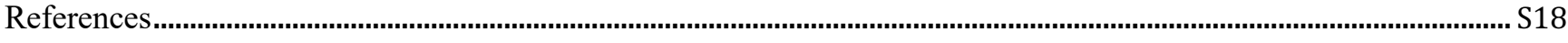

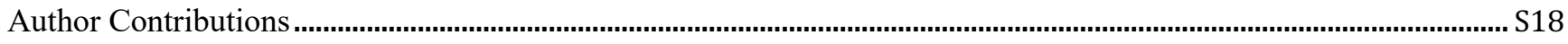

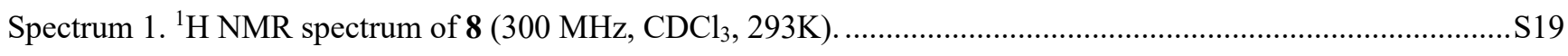

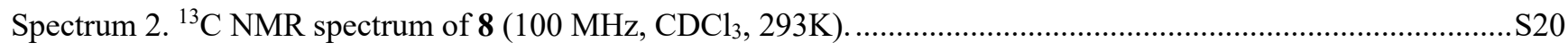

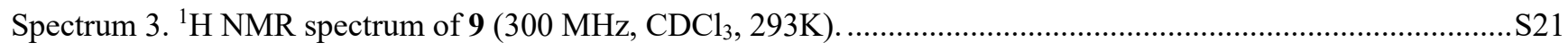

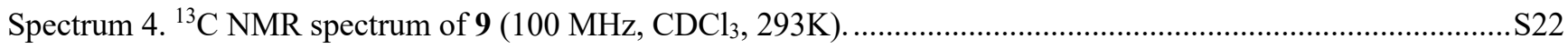

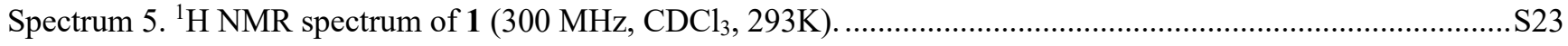

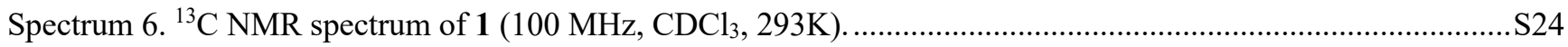




\section{General Techniques}

All reactions were carried out with freshly distilled solvents under anhydrous conditions, unless otherwise noted. All of the flasks used for carrying out reactions were dried in an oven at $80^{\circ} \mathrm{C}$ prior to use. Unless specifically stated, the temperature of a water bath during the evaporation of organic solvents using a rotary evaporator was about $35 \pm 5{ }^{\circ} \mathrm{C}$. All of the syringes in this study were dried in an oven at $80^{\circ} \mathrm{C}$ and stored in a desiccator over Drierite ${ }^{\circledR}$. Tetrahydrofuran (THF) was distilled over sodium metal and benzophenone. Methylene chloride $\left(\mathrm{CH}_{2} \mathrm{Cl}_{2}\right)$ was distilled over calcium hydride. Acetonitrile was distilled from $\mathrm{CaH}_{2}$ and stored over $3 \AA$ molecular sieves. Yields refer to chromatographically and spectroscopically $\left({ }^{1} \mathrm{H}\right.$ NMR $)$ homogenous materials, unless otherwise stated. All reactions were monitored by thinlayer chromatography (TLC) carried out on 0.25 - mm Merck silica gel plates (60F-254) using UV light (254 nm) for visualization or a solution of anisaldehyde in ethanol or a solution of $2.4 \%$ phosphomolybdic acid, $1.4 \%$ phosphoric acid, and 5\% sulfuric acid in water as a developing agents and heat for visualization. Silica gel (230-400 mesh) was used for flash column chromatography. A rotary evaporator was connected to a water aspirator that produced a vacuum pressure of approximately $60 \mathrm{mmHg}$ when it was connected to the evaporator. NMR spectra were recorded on a Bruker Advance spectrometer at $300 \mathrm{MHz}$ or $400 \mathrm{MHz}$. The chemical shifts are given in parts per million (ppm) on a delta $(\delta)$ scale. The solvent peak was used as a reference value: for ${ }^{1} \mathrm{H}$ NMR: $\mathrm{CHCl}_{3}=7.27 \mathrm{ppm}, \mathrm{CH}_{3} \mathrm{OH}=3.31 \mathrm{ppm}, \mathrm{CH}_{3} \mathrm{CN}$ $=2.08$ ppm; for ${ }^{13} \mathrm{C} \mathrm{NMR}: \mathrm{CDCl}_{3}=77.00 \mathrm{ppm}, \mathrm{CD}_{3} \mathrm{OD}=49.00 \mathrm{ppm}$, and $\mathrm{CD}_{3} \mathrm{CN}=1.79 \mathrm{ppm}$ for $\mathrm{CD}_{3}$ or $118.26 \mathrm{ppm}$ for $\mathrm{CN}$. The following abbreviations are used to indicate the multiplicities: $\mathrm{s}=\operatorname{singlet} ; \mathrm{d}=\operatorname{doublet} ; \mathrm{t}=$ triplet; $\mathrm{q}=$ quartet; $\mathrm{m}=$ multiplet; $\mathrm{br}=$ broad. High-resolution mass spectra (HRMS) were recorded on a VG 7070 spectrometer. Infrared (IR) spectra were collected on a Mattson Cygnus 100 spectrometer. Samples for acquiring IR spectra were prepared as a thin film on a $\mathrm{NaCl}$ plate by dissolving the compound in $\mathrm{CH}_{2} \mathrm{Cl}_{2}$ and then evaporating the $\mathrm{CH}_{2} \mathrm{Cl}_{2}$.

All fluorescence measurements (excitation $490 \mathrm{~nm}$, emission 510-570 nm) were carried out using a Promega Biosystems Modulus II Microplate Reader or a HoribaMax Fluorometer unless otherwise stated. Data analysis was performed using GraphPad Prism 8.

\section{Synthesis of 1}

Methyl (E)-2-(6-((3-methoxy-3-oxoprop-1-en-1-yl)oxy)-3-0xo-3H-xanthen-9-yl)benzoate (8)

A suspension of $7^{1}(7.760 \mathrm{~g}, 22.52 \mathrm{mmol})$ in dry $\mathrm{CH}_{2} \mathrm{Cl}_{2}(390 \mathrm{~mL})$ was treated with $N$-methylmorpholine $(683 \mathrm{mg}, 6.76$ $\mathrm{mmol}$ ) and methyl propiolate $(9.467 \mathrm{mg}, 112.6 \mathrm{mmol})$ under a nitrogen atmosphere at $23{ }^{\circ} \mathrm{C}$. After stirring the reaction mixture for $24 \mathrm{~h}$ at the same temperature, silica gel $(24 \mathrm{~g})$ was added, and the mixture was concentrated in vacuo. The resulting crude residue was purified by flash column chromatography $(10 \rightarrow 90 \%$ EtOAc in hexanes) on silica gel $(560 \mathrm{~mL})$ to obtain vinyl ether $\mathbf{8}$ (7.65 g, 79\%) as an orange solid. Data for 8: m.p.: 192.0-193.0 ${ }^{\circ} \mathrm{C}$; $\mathrm{R}_{\mathrm{f}}: 0.25(70 \%$ EtOAc in hexanes); IR (film): $v_{\max }=3060,2923,1722(\mathrm{C}=\mathrm{O}), 1642(\mathrm{C}=\mathrm{O}), 1639(\mathrm{C}=\mathrm{O}), 1595$, $1522,1444,1378,1267,1247,1191,1158,1133,1106,1081,854,707 \mathrm{~cm}^{-1} ;{ }^{1} \mathrm{H}$ NMR

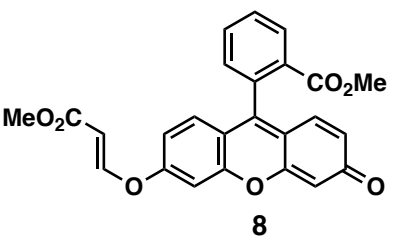
$\left(300 \mathrm{MHz}, \mathrm{CDCl}_{3}, 293 \mathrm{~K}\right): \delta 8.25(\mathrm{dd}, J=7.5,1.5 \mathrm{~Hz}, 1 \mathrm{H}), 7.85(\mathrm{~d}, J=12.0 \mathrm{~Hz}, 1 \mathrm{H}), 7.79(\mathrm{ddd}, J=7.5,7.5,1.2 \mathrm{~Hz}$, 1H), 7.72 (ddd, $J=7.5,7.5,1.2 \mathrm{~Hz}, 1 \mathrm{H}), 7.33$ (dd, $J=7.5,1.2 \mathrm{~Hz}, 1 \mathrm{H}), 7.18$ (d, $J=2.4 \mathrm{~Hz}, 1 \mathrm{H}), 6.98(\mathrm{~d}, J=9.0 \mathrm{~Hz}$, $1 \mathrm{H}), 6.89(\mathrm{dd}, J=9.6,1.8 \mathrm{~Hz}, 1 \mathrm{H}), 6.87(\mathrm{~d}, J=9.6 \mathrm{~Hz}, 1 \mathrm{H}), 6.56(\mathrm{dd}, J=9.6,1.8 \mathrm{~Hz}, 1 \mathrm{H}), 6.46(\mathrm{~d}, J=1.8 \mathrm{~Hz}, 1 \mathrm{H})$, $5.79(\mathrm{~d}, J=12.0 \mathrm{~Hz}, 1 \mathrm{H}), 3.76$ (s, 3H), $3.66(\mathrm{~s}, 3 \mathrm{H}) ;{ }^{13} \mathrm{C} \mathrm{NMR}\left(100 \mathrm{MHz}, \mathrm{CDCl}_{3}, 293 \mathrm{~K}\right): \delta 185.9,166.8,165.5,158.9$, 158.5, 156.1, 153.4, 148.7, 134.3, 132.9, 131.3, 130.7, 130.6, 130.3, 130.2, 129.9, 129.3, 119.2, 118.0, 114.1, 106.3, 105.1, 104.7, 52.5, 51.6; HRMS (ESI-TOF) $m / z$ : $[\mathrm{M}+\mathrm{H}]+$ calcd. for $\mathrm{C}_{25} \mathrm{H}_{19} \mathrm{O}_{7} 431.1110$, found 431.1125 .

\section{(S,E)-6'-((3-Hydroxyprop-1-en-1-yl)oxy)-3H-spiro[isobenzofuran-1,9'-xanthen]-3'-ol (9)}

A $1 \mathrm{M}$ solution of diisobutylaluminum hydride in hexanes $(1.80 \mathrm{~mL}, 1.80 \mathrm{mmol})$ was added dropwise to a flask containing ester $8(100 \mathrm{mg}, 0.23 \mathrm{mmol})$ in dry $\mathrm{CH}_{2} \mathrm{Cl}_{2}(1.5 \mathrm{~mL})$ under a nitrogen atmosphere at $-78^{\circ} \mathrm{C}$. After stirring the reaction mixture for $15 \mathrm{~min}$ at the same temperature, the flask was warmed to $23{ }^{\circ} \mathrm{C}$. The mixture was stirred at the same temperature for an additional 2 $\mathrm{h}$, and then the reaction was quenched with $1 \mathrm{M}$ aqueous sodium potassium tartrate $(2 \mathrm{~mL})$ at $0{ }^{\circ} \mathrm{C}$. After stirring the mixture for $3 \mathrm{~h}$ at $23{ }^{\circ} \mathrm{C}, \mathrm{Et}_{2} \mathrm{O}(5 \mathrm{~mL})$ and DDQ $(57 \mathrm{mg}, 0.25$

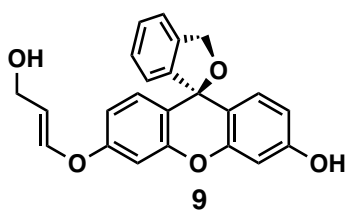


mmol) were added at $0{ }^{\circ} \mathrm{C}$ and the resulting mixture was stirred at the same temperature for $1 \mathrm{~h}$. The combined organic and aqueous layers were filtered through a pad of Celite, and the pad was rinsed with EtOAc. The filtrate was dried under $\mathrm{Na}_{2} \mathrm{SO}_{4}$, filtered through a cotton plug, and concentrated in vacuo. The resulting crude residue was purified by flash column chromatography $(10 \rightarrow 60 \%$ EtOAc in hexanes) on silica gel $(20 \mathrm{~mL})$ to obtain alcohol $9(57 \mathrm{mg}, 66 \%)$ as a pale yellow solid and byproduct $\mathbf{5}(14 \mathrm{mg}, 20 \%)$ as an orange solid. Data for 9: m.p.: $169.0-170.0{ }^{\circ} \mathrm{C}$; $\mathrm{R}_{\mathrm{f}}$ : $0.52(70 \%$ EtOAc in hexanes); IR (film): $v_{\max }=3378(\mathrm{O}-\mathrm{H}), 2923,2853,1673,1601,1480,1434,1409,1266,1173,1114,1004$, 926, 854, $722 \mathrm{~cm}^{-1}$; ${ }^{1} \mathrm{H}$ NMR (300 MHz, $1 \% \mathrm{CD}_{3} \mathrm{OD}$ in $\left.\mathrm{CDCl}_{3}, 293 \mathrm{~K}\right): \delta$ 7.36-7.37 (m, 2H), 7.23-7.28 (m, $\left.1 \mathrm{H}\right), 6.91$ $(\mathrm{d}, J=2.4 \mathrm{~Hz}, 1 \mathrm{H}), 6.88(\mathrm{br} \mathrm{s}, 1 \mathrm{H}), 6.84(\mathrm{~d}, J=2.4 \mathrm{~Hz}, 1 \mathrm{H}), 6.77(\mathrm{~d}, J=8.4 \mathrm{~Hz}, 1 \mathrm{H}), 6.68-6.70(\mathrm{~m}, 1 \mathrm{H}), 6.70(\mathrm{dt}, J=$ 12.0, $1.8 \mathrm{~Hz}, 1 \mathrm{H}), 6.60(\mathrm{~d}, J=2.4 \mathrm{~Hz}, 1 \mathrm{H}), 6.52(\mathrm{dd}, J=8.7,2.4 \mathrm{~Hz}, 1 \mathrm{H}), 5.57$ (dt, $J=12.0,7.2 \mathrm{~Hz}, 1 \mathrm{H}), 5.29$ (s, 2H), $4.15(\mathrm{dd}, J=7.2,1.8 \mathrm{~Hz}, 2 \mathrm{H}) ;{ }^{13} \mathrm{C}$ NMR $\left(100 \mathrm{MHz}, \mathrm{CDCl}_{3}, 293 \mathrm{~K}\right): \delta 157.4,157.1,151.4,151.3,144.8,144.3,138.7$, $130.1,130.0,128.5,128.2,123.9,120.7,119.0,116.0,112.9,112.1,111.6,103.9,102.7,83.9,71.8,59.6$; HRMS (ESITOF) $m / z:[\mathrm{M}+\mathrm{H}]+$ calcd. for $\mathrm{C}_{23} \mathrm{H}_{19} \mathrm{O}_{5}$ 375.1227, found 375.1209.

\section{(S,E)-6'-((3-(Phenylselanyl)prop-1-en-1-yl)oxy)-3H-spiro[isobenzofuran-1,9'-xanthen]-3'-ol (1)}

A $10-\mathrm{mL}$ round-bottomed flask equipped with a Teflon-coated magnetic stir bar containing 9 (85 mg, $0.23 \mathrm{mmol})$ was purged with argon. The flask was treated with THF $(1.2 \mathrm{~mL}),{ }^{\mathrm{n}} \mathrm{Bu}_{3} \mathrm{P}(67 \mu \mathrm{L}, 0.27 \mathrm{mmol})$, and $\mathrm{PhSeCN}(29 \mu \mathrm{L}, 0.23$ $\mathrm{mmol}$ ) sequentially at $0{ }^{\circ} \mathrm{C}$. The mixture was stirred at the same temperature for $30 \mathrm{~min}$ and was then quenched with sat. $\mathrm{NH}_{4} \mathrm{Cl}$. The quenched mixture was extracted with EtOAc $(3 \times$ $15 \mathrm{~mL}$ ). The combined organic layers were dried over $\mathrm{Na}_{2} \mathrm{SO}_{4}$ and concentrated in vacuo. The resulting crude residue was purified by flash column chromatography $\left(\mathrm{SiO}_{2}\right.$, eluent: $5 \% \rightarrow 25 \%$ EtOAc in hexanes; $30 \mathrm{~mL}$ each) to obtain 1 (48 $\mathrm{mg}, 41 \%)$ as pale-yellow solid.

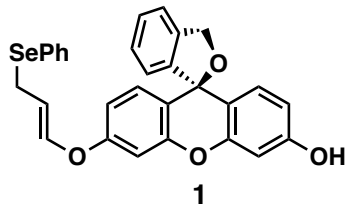
Data for 1: m.p.: $125.5-126.5^{\circ} \mathrm{C}$; $\mathrm{R}_{\mathrm{f}}$ : 0.56 (40\% EtOAc in hexanes); IR (film): $v_{\max }=3286$ (broad, O-H), 2923, 2853, 2360, 1664, 1609, 1496, 1458, 1427, 1331, 1266, 1247, 1210, 1177, 1111, 997, 928, 846, 804, 757, 737, $691 \mathrm{~cm}^{-1} ;{ }^{1} \mathrm{H}$ NMR (300 MHz, 1\% CD $\left.\mathrm{CD}_{3} \mathrm{OD} \mathrm{CDCl}_{3}, 293 \mathrm{~K}\right): \delta 7.56(\mathrm{dd}, J=6.0,1.2 \mathrm{~Hz}, 2 \mathrm{H}), 7.36-7.34(\mathrm{~m}, 2 \mathrm{H}), 7.32-7.31(\mathrm{~m}$, $3 \mathrm{H}), 7.27-7.26(\mathrm{~m}, 1 \mathrm{H}), 6.88(\mathrm{~d}, J=7.5 \mathrm{~Hz}, 1 \mathrm{H}), 6.83(\mathrm{dd}, J=8.1,8.1 \mathrm{~Hz}, 2 \mathrm{H}), 6.66(\mathrm{~d}, J=2.4 \mathrm{~Hz}, 1 \mathrm{H}), 6.54(\mathrm{~m}, 3 \mathrm{H})$, $6.30(\mathrm{~d}, J=12.0 \mathrm{~Hz}, 1 \mathrm{H}), 5.57(\mathrm{dt}, J=12.0,8.4 \mathrm{~Hz}, 1 \mathrm{H}), 5.27(\mathrm{~s}, 2 \mathrm{H}), 3.45(\mathrm{dd}, J=8.1,0.9 \mathrm{~Hz}, 2 \mathrm{H}) ;{ }^{13} \mathrm{C}$ NMR $(100$ $\left.\mathrm{MHz}, \mathrm{CDCl}_{3}, 293 \mathrm{~K}\right): \delta 157.5,156.5,151.4,151.3,144.6,143.1,139.0,134.4,133.2,130.1,130.0,129.4,129.2,128.9$, $128.5,128.2,127.7,123.9,120.7,119.1,117.0,112.5,111.9,110.5,103.6,102.7,83.6,72.0,25.6$; HRMS (ESI-TOF) $m / z$ : [M - H] calcd. for $\mathrm{C}_{29} \mathrm{H}_{21} \mathrm{O}_{4} \mathrm{Se}$ 513.0610, found 513.0610. 


\section{Mechanistic studies}

Probe $1(1.8 \mathrm{mg})$ in $\mathrm{CD}_{3} \mathrm{OD}(0.75 \mathrm{~mL})$ was treated with $943 \mathrm{mM} \mathrm{H}_{2} \mathrm{O}_{2}(1.9 \mu \mathrm{L})$. The crude reaction mixture was monitored in situ by ${ }^{1} \mathrm{H}$ NMR spectroscopy and analyzed against known standards (5 and acrolein). Figure 3 shows that both 5 and acrolein were formed during the reaction.

\section{HPLC chromatogram of selenide 1 and phenol 5}

Column: Agilent 1200 system; Flow rate: $0.6 \mathrm{~mL} / \mathrm{min}$; Max. Pressure (bar): 600

Elution conditions: $\mathrm{H}_{2} \mathrm{O} / \mathrm{MeCN} 95: 5$ to $20: 80,0-15 \mathrm{~min} ; 20: 80$ to $0: 100,15-20 \mathrm{~min} ; 0: 100,20-25 \mathrm{~min} ; 0: 100$ to $95: 5$, 25-30 min

Retention time for 1: $20.1 \mathrm{~min}$

Retention time for 5: $27.6 \mathrm{~min}$

(a)

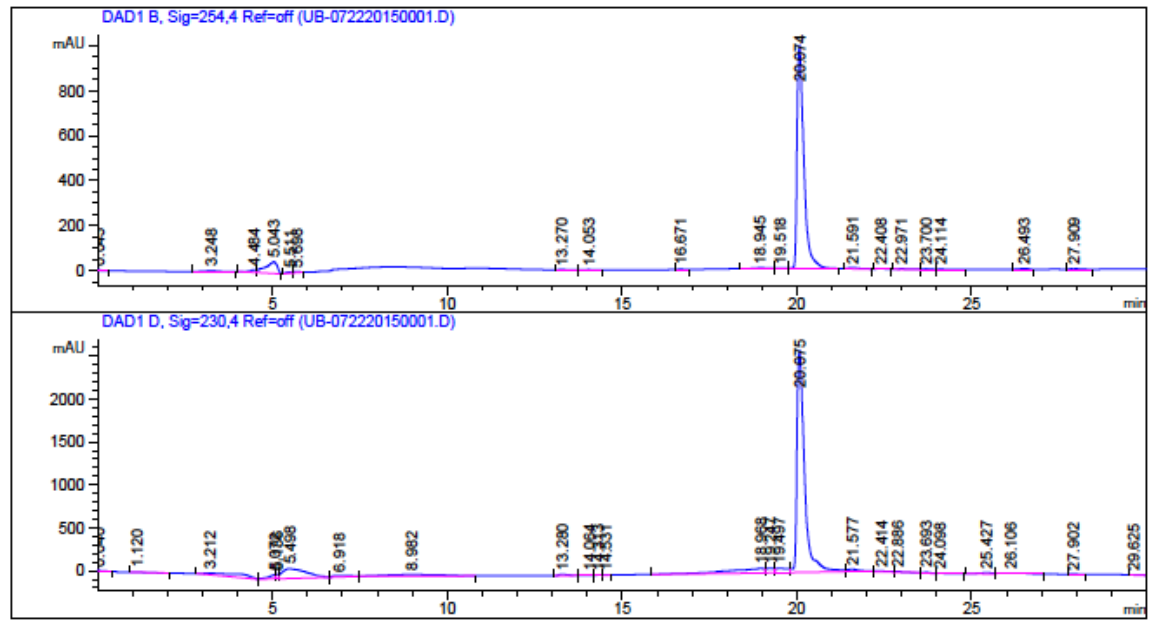

(b)

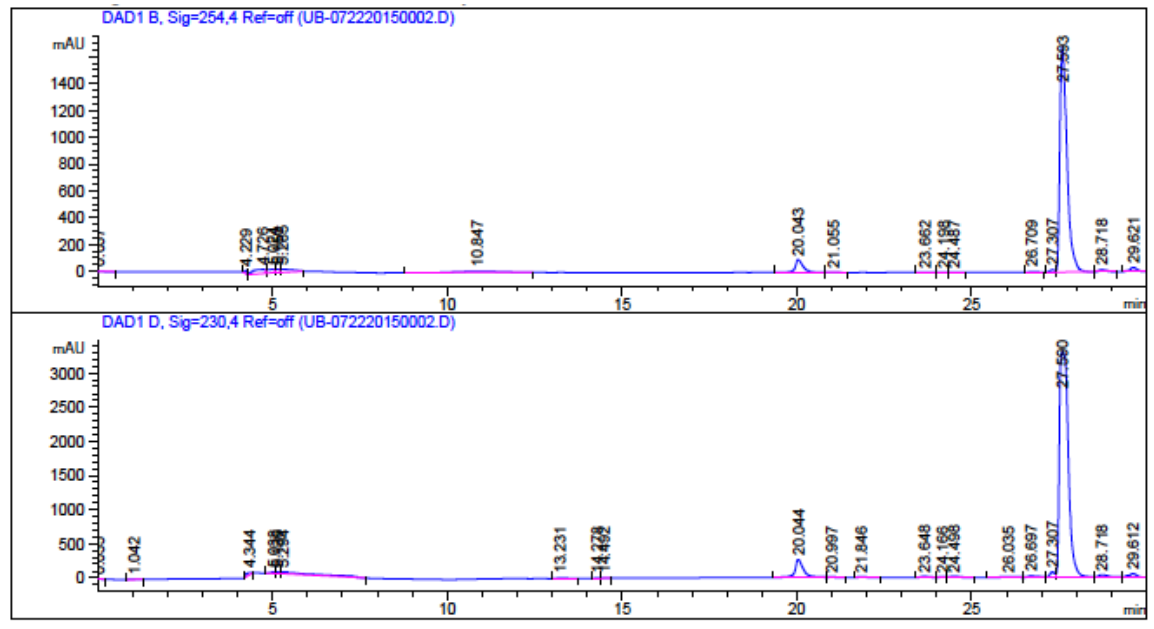


(c)

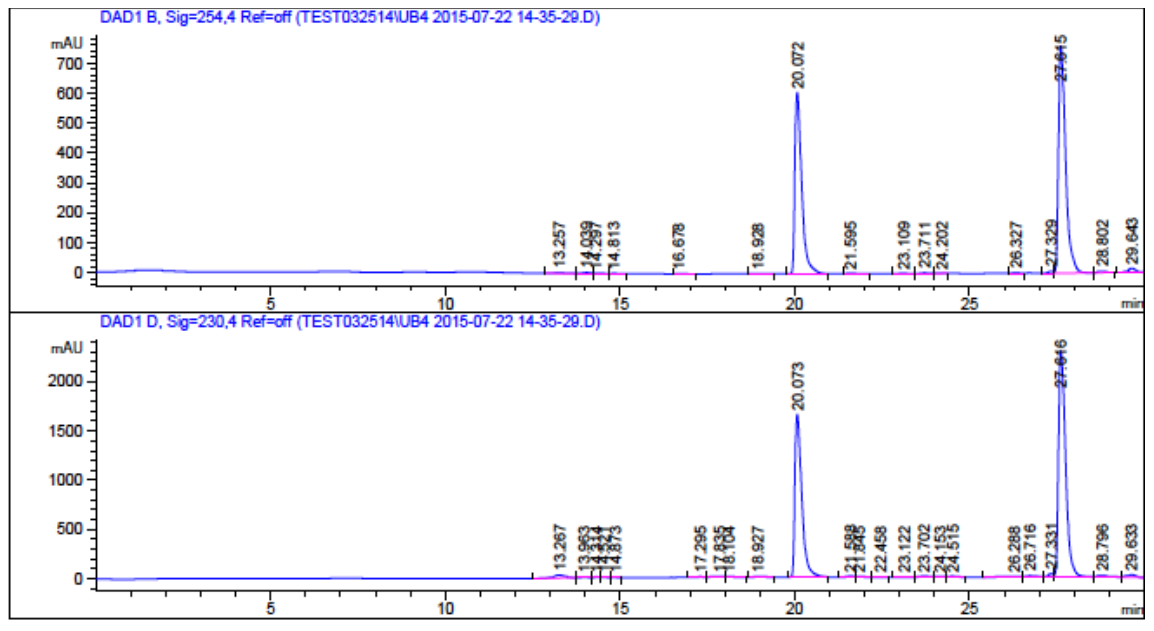

(d)

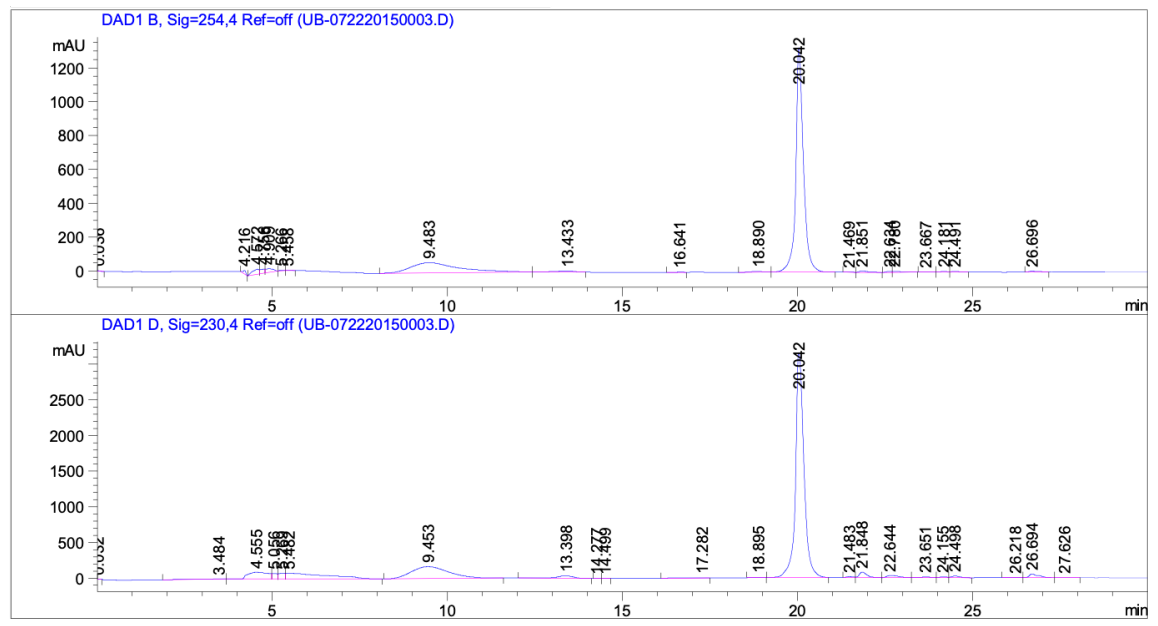

(e)

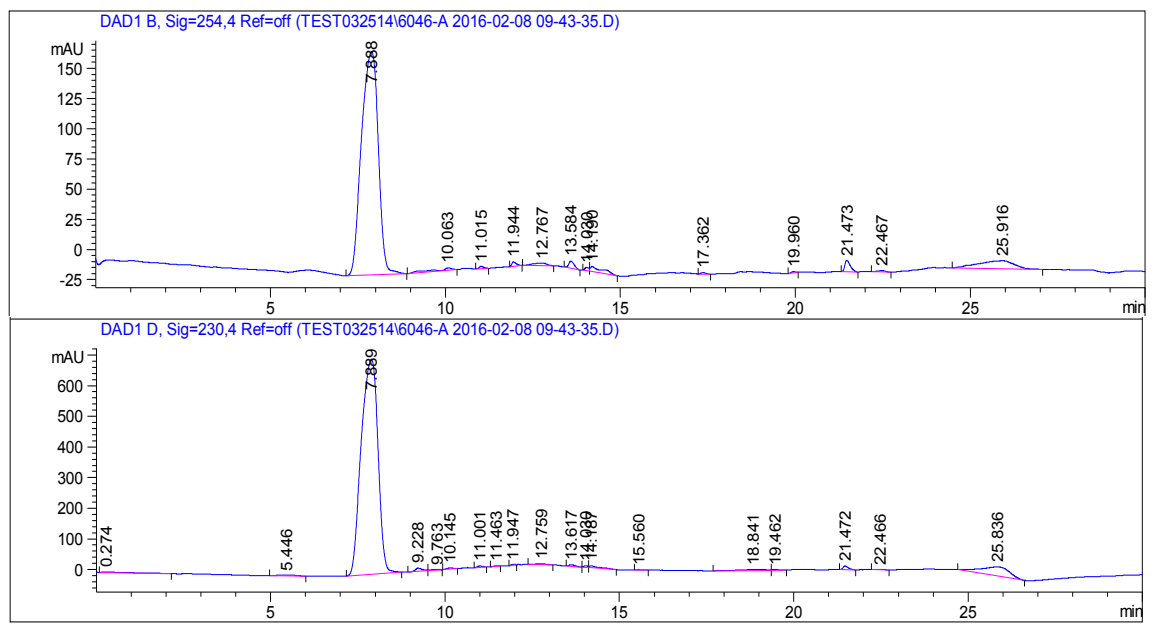

Figure S1. HPLC chromatograms of (a) authentic sample of selenide 1 (b) phenol 5 (c) selenide 1 + phenol 5 (d) crude reaction mixture of selenide 1 +1 equiv $\mathrm{H}_{2} \mathrm{O}_{2}$, and (e) authentic sample of $\mathrm{PhSeO}_{2} \mathrm{H}$ acquired at $\lambda=254 \mathrm{~nm}$ and $230 \mathrm{~nm}$, respectively. 


\section{Stability studies}

To study the stability of $\mathbf{1}$, the ${ }^{1} \mathrm{H}$ NMR spectra of $\mathbf{1}$ in DMSO- $d_{6}$ were obtained at specified intervals (days $1,7,14,21$, 30 and 60). The solution was left at room temperature and in air throughout the entire period.
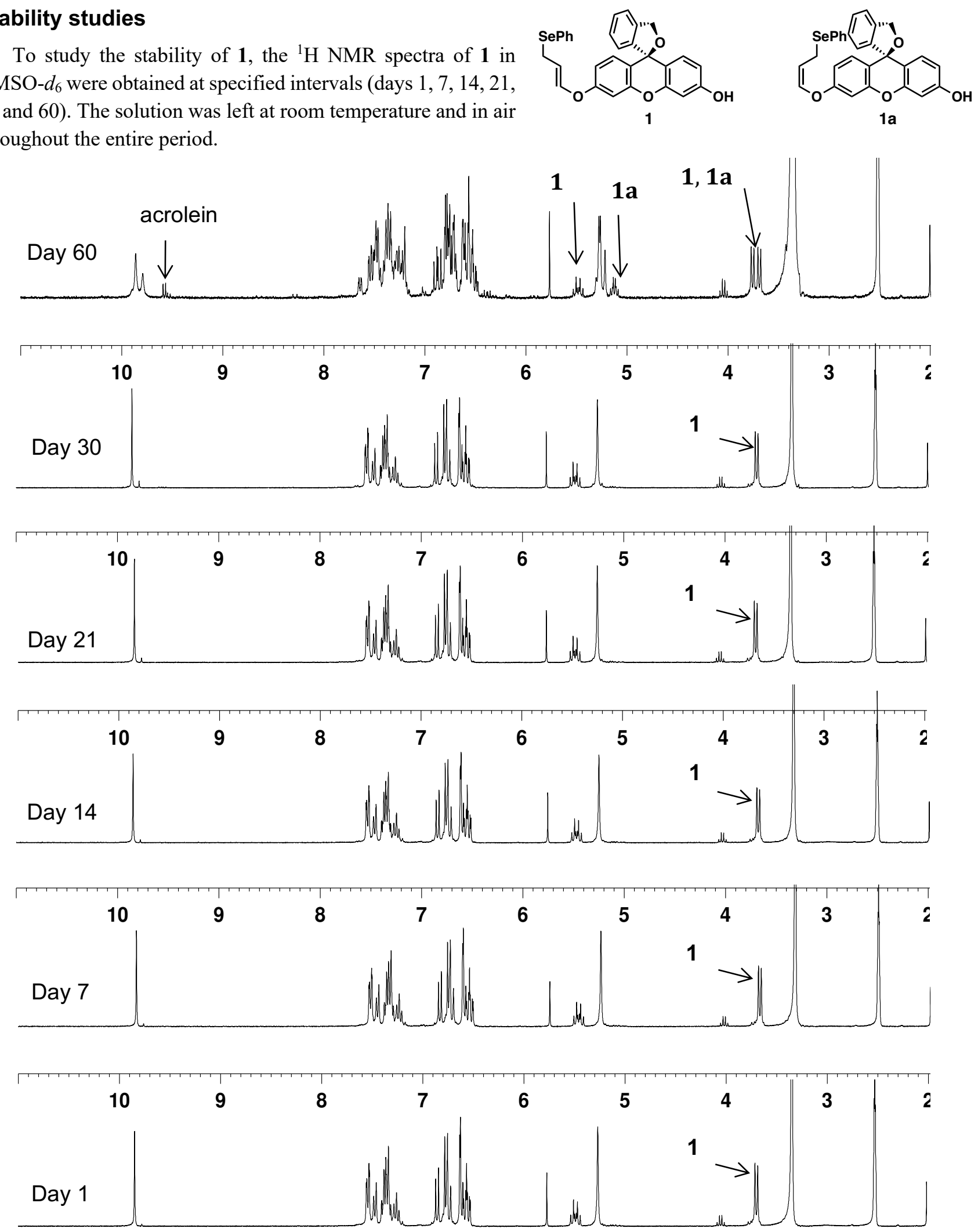

10

9

$8 \quad 7$

$7 \quad 6$

65

4

3

Figure S2. ${ }^{1} \mathrm{H}$ NMR spectra (300 MHz, DMSO- $\left.d_{6}\right)$ of 1 recorded on days $1,7,14,21,30$ and 60. 


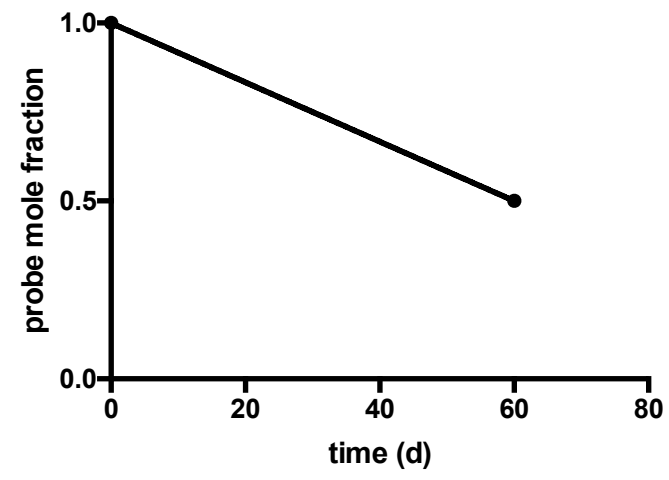

Figure S3. Half-life of probe 1.

\section{Determination of the difference in fluorescence intensity between selenide 1 and phenol 5}

Solutions containing ultrapure water $(681 \mu \mathrm{L}), 1.2 \mathrm{M}$ phosphate $\mathrm{pH} 7$ buffer $(31 \mu \mathrm{L})$, DMSO $(28.1 \mu \mathrm{L})$, and $80 \mu \mathrm{M} 1$ or phenol 5 in DMSO $(9.4 \mu \mathrm{L})$ were made. Aliquots of these solutions $(200 \mu \mathrm{L})$ were transferred to the wells of a black 96-well plate and the fluorescence was measured.

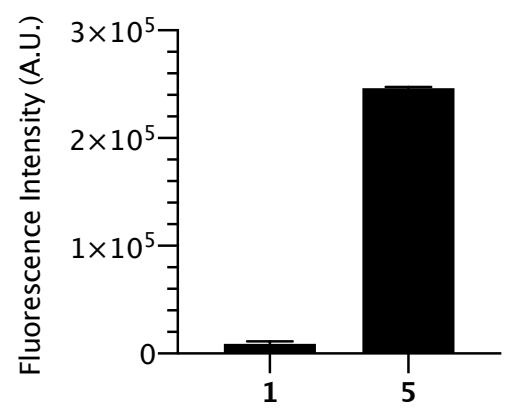

Figure S4. Difference in fluorescence intensity between selenide $\mathbf{1}$ and phenol $\mathbf{5}$.

\begin{tabular}{c|ccc}
\hline Compound & \multicolumn{3}{|c}{ Fluorescence Intensity } \\
\hline $\mathbf{1}$ & 7,053 & 11,524 & 8,556 \\
$\mathbf{5}$ & 244,687 & 247,204 & 246,848 \\
\hline
\end{tabular}

Table S1. Raw fluorescence values for Figure S4. $n=3$. 


\section{Pseudo first order kinetics and evaluation of second order rate constant}

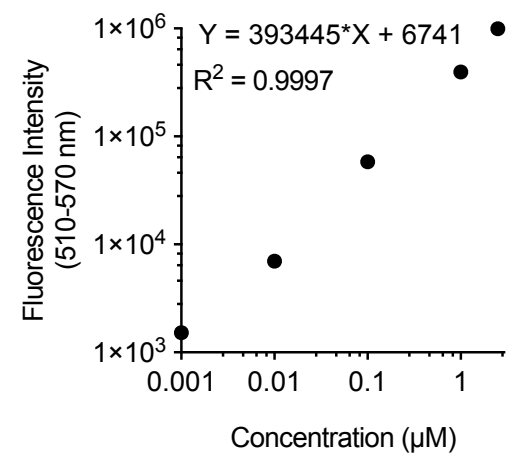

Figure S5. Calibration curve for phenol 5 shown on a log scale: $200 \mu \mathrm{L}, 5 \% \mathrm{MeCN}$ in $50 \mathrm{mM} \mathrm{pH} 7.5 \mathrm{HEPES}$ buffer. $n=2$. Error bars are invisible because they are smaller than the dots.

\begin{tabular}{ll} 
Best-fit values & \\
Slope & $393445 \pm 2396$ \\
Y-intercept when $X=0.0$ & $6741 \pm 2887$ \\
X-intercept when $Y=0.0$ & -0.01713 \\
1/slope & $2.54 \mathrm{E}-06$ \\
95\% Confidence Intervals & \\
Slope & 387921 to 398969 \\
Y-intercept when X=0.0 & 84.06 to 13397 \\
X-intercept when $Y=0.0$ & -0.03434 to -0.0002119 \\
Goodness of Fit & \\
R square & 0.9997 \\
Sy.X & 7307 \\
Is slope significantly non-zero? & \\
F & \\
DFn, DFd & 26975 \\
P value & $1.000,8.000$ \\
Deviation from zero? & $<0.0001$ \\
Data & Significant \\
Number of $X$ values & \\
Maximum number of $Y$ replicates & 5 \\
Total number of values & \\
Number of missing values & \\
& \\
\hline & \\
\hline
\end{tabular}




\begin{tabular}{|c|c|c|c|c|c|c|c|c|c|}
\hline \multirow[b]{2}{*}{ Time (s) } & \multicolumn{3}{|c|}{$\mathrm{F}-\mathrm{F}_{0}(515 \mathrm{~nm}) ;\left[\mathrm{H}_{2} \mathrm{O}_{2}\right]=0.625 \mathrm{mM}$} & \multicolumn{3}{|c|}{$\mathrm{F}-\mathrm{F}_{0}(515 \mathrm{~nm}) ;\left[\mathrm{H}_{2} \mathrm{O}_{2}\right]=1.25 \mathrm{mM}$} & \multicolumn{3}{|c|}{$\mathrm{F}-\mathrm{F}_{0}(515 \mathrm{~nm}) ;\left[\mathrm{H}_{2} \mathrm{O}_{2}\right]=2.5 \mathrm{mM}$} \\
\hline & Expt. 1 & Expt. 2 & Expt. 3 & Expt. 1 & Expt. 2 & Expt. 3 & Expt.1 & Expt. 2 & Expt. 3 \\
\hline 30 & 145,691 & 101,161 & 83,026 & 255,659 & 258,915 & 225,047 & 425,024 & 405,551 & 398,309 \\
\hline 90 & 220,196 & 277,036 & 236,883 & 364,712 & 517,271 & 484,926 & 539,467 & 612,814 & 630,136 \\
\hline 150 & 301,900 & 391,059 & 348,470 & 463,364 & 607,290 & 590,662 & 601,940 & 657,981 & 671,943 \\
\hline 210 & 355,049 & 458,596 & 422,910 & 514,663 & 641,798 & 639,332 & 627,168 & 666,435 & 680,181 \\
\hline 270 & 390,358 & 499,861 & 473,964 & 549,297 & 656,229 & 660,178 & 636,230 & 665,190 & 679,336 \\
\hline 330 & 421,561 & 522,358 & 509,584 & 572,635 & 661,539 & 664,254 & 638,753 & 666,173 & 674,138 \\
\hline 390 & 450,025 & 534,705 & 536,252 & 589,797 & 665,178 & 666,753 & 641,141 & 663,899 & 664,993 \\
\hline 450 & 477,638 & 541,922 & 555,207 & 601,493 & 663,842 & 669,367 & 640,270 & 661,893 & 664,413 \\
\hline 510 & 501,767 & 546,290 & 569,868 & 606,377 & 663,608 & 673,539 & 639,383 & 659,509 & 664,003 \\
\hline 570 & 524,121 & 550,122 & 581,518 & 612,207 & 662,594 & 675,671 & 637,346 & 658,746 & 663,104 \\
\hline 630 & 543,908 & 551,490 & 591,076 & 614,405 & 663,947 & 677,477 & 637,422 & 656,826 & 661,222 \\
\hline 690 & 559,985 & 551,741 & 599,176 & 616,203 & 663,123 & 679,640 & 636,174 & 654,911 & 659,002 \\
\hline 750 & 570,897 & 553,475 & 603,780 & 616,371 & 663,595 & 679,888 & 634,294 & 654,494 & 657,410 \\
\hline 810 & 580,693 & 553,568 & 609,902 & 614,783 & 663,765 & 683,016 & 631,953 & 653,606 & 654,988 \\
\hline 870 & 587,536 & 552,326 & 614,108 & 614,819 & 662,173 & 685,799 & 631,346 & 651,140 & 655,338 \\
\hline
\end{tabular}

Table S2. Raw data for Figure 4a.

\section{Raw data for studying pseudo first order kinetics}

Rate $=\mathrm{k}^{\prime}[\mathbf{1}]$; where $\mathrm{k}$ ' $=\mathrm{k}\left[\mathrm{H}_{2} \mathrm{O}_{2}\right]$

Final concentration: $\left[\mathrm{H}_{2} \mathrm{O}_{2}\right]=0.625 \mathrm{mM}, 1.25 \mathrm{mM}$ and $2.5 \mathrm{mM}$; [1] $=1.7 \mu \mathrm{M} ; 5 \% \mathrm{MeCN}$ in pH $7.5 \mathrm{HEPES}$ buffer $50 \mathrm{mM}$. All reactions were performed in triplicate in a $96-$ well plate.

Calculating [1] from the standard curve of 5. Fluorescence Intensity $=393445 \cdot[5]+6741 ; R^{2}=0.9997$.

\begin{tabular}{c|ccc|ccc|ccc}
\hline & \multicolumn{3}{|c}{$\begin{array}{c}{[1] \mu \mathrm{M}} \\
{\left[\mathrm{H}_{2} \mathrm{O}_{2}\right]=0.625 \mathrm{mM}}\end{array}$} & \multicolumn{3}{|c|}{$\begin{array}{c}{[1] \mu \mathrm{M}} \\
{\left[\mathrm{H}_{2} \mathrm{O}_{2}\right]=1.25 \mathrm{mM}}\end{array}$} & \multicolumn{3}{c}{$\left[\begin{array}{c}{[1] \mu \mathrm{M}} \\
{\left[\mathrm{H}_{2} \mathrm{O}_{2}\right]=2.5 \mathrm{mM}}\end{array}\right.$} \\
\hline $\begin{array}{c}\text { Time } \\
(\mathrm{s})\end{array}$ & Exp. 1 & Exp. 2 & Exp. 3 & Exp. 1 & Exp. 2 & Exp. 3 & Exp. 1 & Exp. 2 & Exp. 3 \\
\hline 30 & 1.3453 & 1.4596 & 1.5061 & 1.0631 & 1.0547 & 1.1417 & 0.6285 & 0.6785 & 0.6971 \\
90 & 1.1541 & 1.0082 & 1.1113 & 0.7833 & 0.3918 & 0.4748 & 0.3348 & 0.1466 & 0.1022 \\
150 & 0.9444 & 0.7157 & 0.8249 & 0.5301 & 0.1608 & 0.2035 & 0.1745 & 0.0307 & -0.005 \\
210 & 0.8081 & 0.5424 & 0.6339 & 0.3985 & 0.0722 & 0.0786 & 0.1098 & 0.0090 & -0.026 \\
270 & 0.7175 & 0.4365 & 0.5029 & 0.3096 & 0.0352 & 0.0251 & 0.0865 & 0.0122 & -0.024 \\
330 & 0.6374 & 0.3787 & 0.4115 & 0.2497 & 0.0216 & 0.0146 & 0.0801 & 0.0097 & -0.010 \\
390 & 0.5643 & 0.3470 & 0.3431 & 0.2057 & 0.0122 & 0.0082 & 0.0739 & 0.0155 & 0.0127 \\
450 & 0.4935 & 0.3285 & 0.2944 & 0.1757 & 0.0157 & 0.0015 & 0.0762 & 0.0207 & 0.0142 \\
510 & 0.4316 & 0.3173 & 0.2568 & 0.1631 & 0.0163 & -0.009 & 0.0784 & 0.0268 & 0.0153 \\
570 & 0.3742 & 0.3075 & 0.2269 & 0.1482 & 0.0189 & -0.014 & 0.0837 & 0.0288 & 0.0176 \\
630 & 0.3234 & 0.3040 & 0.2024 & 0.1425 & 0.0154 & -0.019 & 0.0835 & 0.0337 & 0.0224 \\
690 & 0.2822 & 0.3033 & 0.1816 & 0.1379 & 0.0175 & -0.024 & 0.0867 & 0.0386 & 0.0281 \\
750 & 0.2542 & 0.2989 & 0.1698 & 0.1375 & 0.0163 & -0.025 & 0.0915 & 0.0397 & 0.0322 \\
810 & 0.2290 & 0.2986 & 0.1541 & 0.1416 & 0.0159 & -0.033 & 0.0975 & 0.0419 & 0.0384 \\
870 & 0.2115 & 0.3018 & 0.1433 & 0.1415 & 0.0200 & -0.040 & 0.0991 & 0.0483 & 0.0375 \\
\hline
\end{tabular}

Table S3. Raw data for Figure 4b. 


\begin{tabular}{cc}
\hline$\left[\mathrm{H}_{2} \mathrm{O}_{2}\right](\mathrm{mM})$ & Slope $\mathrm{k}^{\prime}\left(\mathrm{s}^{-1}\right)$ \\
\hline 2.5 & 0.02432 \\
1.25 & 0.01359 \\
0.625 & 0.00251 \\
\hline
\end{tabular}

Table S4. Slope ( $\left.k^{\prime}\right)$ obtained from the plot of In [1] vs time.

From Figure 4b, three values of k' were obtained for three different concentrations of $\mathrm{H}_{2} \mathrm{O}_{2}$. Under pseudo first order conditions, $\mathrm{k}^{\prime}=\mathrm{k}\left[\mathrm{H}_{2} \mathrm{O}_{2}\right]$. So, a plot of observed rate constant $\mathrm{k}^{\prime}$ vs $\left[\mathrm{H}_{2} \mathrm{O}_{2}\right]$ yielded the second order rate constant $\mathrm{k}$ as the slope of the linear plot. After all calculations, it was found that second order rate constant $\mathrm{k}=9.82 \pm 1.11 \mathrm{M}^{-}$ ${ }^{1} \mathrm{~s}^{-1}$.

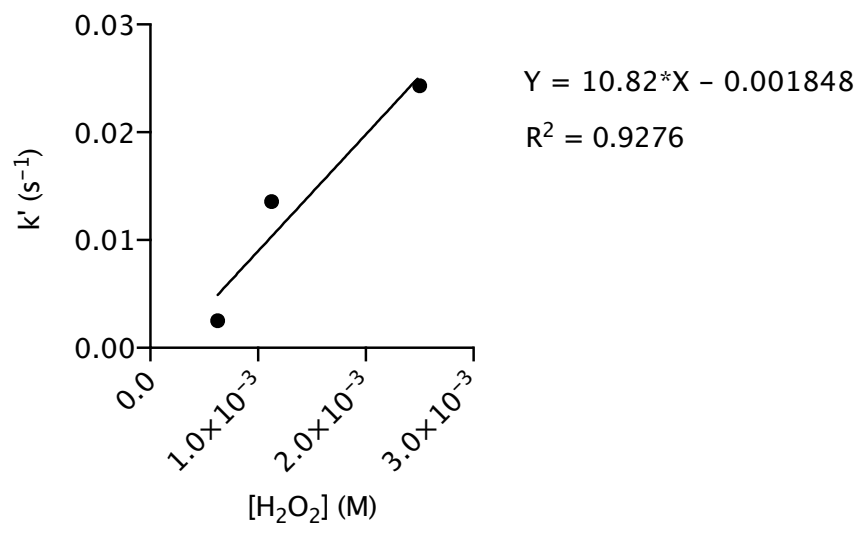

Figure S6. Plot of k' vs time to obtain second order rate constant k.

\section{Reaction of 1 with $\mathrm{H}_{2} \mathrm{O}_{2}$}

A solution of 0-159 $\mu \mathrm{M} \mathrm{H}_{2} \mathrm{O}_{2}$ in 5:95 MeCN/50 mM phosphate $\mathrm{pH} 7$ buffer $(180 \mu \mathrm{L})$ was added to the wells of a black 96-well plate. A solution of $100 \mu \mathrm{M} 1$ in $\mathrm{MeCN}(20 \mu \mathrm{L})$ was then added to the wells. The solutions were allowed to incubate at $25^{\circ} \mathrm{C}$ for $20 \mathrm{~min}$ before the fluorescence was measured.

\section{Determining selectivity of 1 : Reaction with $\mathrm{O}_{2}{ }^{--}$}

A solution of $100 \mu \mathrm{M} 1$ in ethanol $(20 \mu \mathrm{L})$ was added to $5: 95$ methanol/50 mM phosphate $\mathrm{pH} 7$ buffer $(140 \mu \mathrm{L})$. Then, either 0,10 , or $10^{4} \mathrm{U} / \mathrm{mL}$ catalase $(20 \mu \mathrm{L})$ was added to the mixtures. These solutions were transferred to centrifuge tubes containing solid potassium superoxide ( $\sim 3 \mathrm{mg} /$ sample). A control containing $100 \mu \mathrm{M} 1$ in ethanol $(20 \mu \mathrm{L}), 5: 95$ methanol/50 mM phosphate $\mathrm{pH} 7$ buffer $(160 \mu \mathrm{L})$, and $700 \mathrm{mM} \mathrm{H}_{2} \mathrm{O}_{2}(20 \mu \mathrm{L})$ was also generated. The solutions were allowed to incubate at $25^{\circ} \mathrm{C}$ for 15 min prior to measuring fluorescence. 


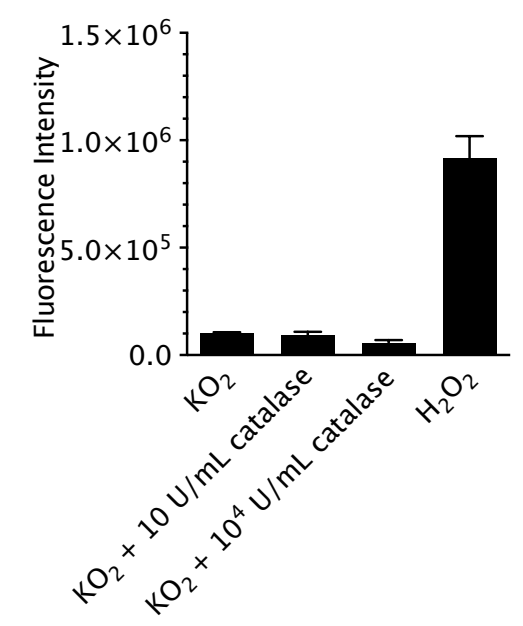

Figure S7. Determining selectivity of 1: Reaction with $\mathrm{O}_{2}{ }^{-*}$.

\begin{tabular}{c|ccc}
\hline Sample & \multicolumn{3}{|c}{ Fluorescence Intensity } \\
\hline $\mathrm{KO}_{2}$ & 106,099 & 92,938 & 99,300 \\
$\mathrm{KO}_{2}+10 \mathrm{U} / \mathrm{mL}$ catalase & 104,768 & 72,151 & 98,514 \\
$\mathrm{KO}_{2}+10^{4} \mathrm{U} / \mathrm{mL}$ catalase & 63,553 & 41,950 & 67,009 \\
$\mathrm{H}_{2} \mathrm{O}_{2}$ & 937,451 & $1,008,330$ & 803,382 \\
\hline
\end{tabular}

Table S5. Raw fluorescence values for determining selectivity of 1 : Reaction with $\mathrm{O}_{2}{ }^{*} \cdot n=3$.

\section{Determining selectivity of 1 : Reaction with ${ }^{1} \mathrm{O}_{2}$}

Probe 1 was titrated with $\mathrm{NaMoO}_{4}$ and $\mathrm{H}_{2} \mathrm{O}_{2}$ to determine whether ${ }^{1} \mathrm{O}_{2}$ reacted with the probe. A solution of $100 \mu \mathrm{M} 1$ in ethanol $(20 \mu \mathrm{L})$ was added to $5: 95$ methanol/50 mM phosphate $\mathrm{pH} 7$ buffer $(140 \mu \mathrm{L})$. Water, $1 \mathrm{mM}$ sodium azide, or $10^{4} \mathrm{U} / \mathrm{mL}$ catalase $(20 \mu \mathrm{L})$ was added to the mixture. $\mathrm{NaMoO}_{4} \cdot 2 \mathrm{H}_{2} \mathrm{O}(11.1 \mathrm{mg})$ was added to ultrapure water $(2.00$ $\mathrm{mL}$ ). This solution was diluted to $20 \mu \mathrm{M}, 200 \mu \mathrm{M}$, and $2.00 \mathrm{mM}$. $\mathrm{H}_{2} \mathrm{O}_{2}$ was diluted to $200 \mu \mathrm{M}$ and $2.00 \mathrm{mM}$. Equal volumes of $\mathrm{NaMoO}_{4}$ solution and $\mathrm{H}_{2} \mathrm{O}_{2}$ were added together, and an aliquot $(20 \mu \mathrm{L})$ was immediately transferred to the solution containing 1 . The fluorescence intensity was measured immediately and again after incubation at $25^{\circ} \mathrm{C}$ for 40 $\min$.

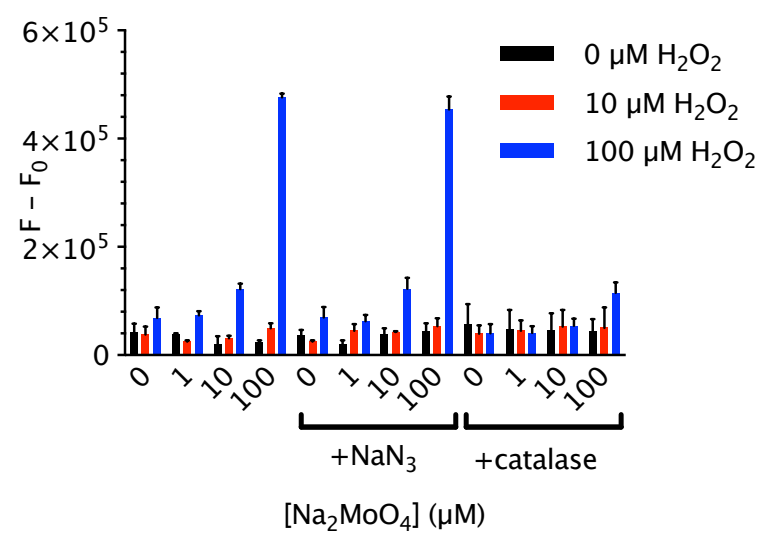

Figure S8. Determining selectivity of 1 : Reaction with ${ }^{1} \mathrm{O}_{2}$. 


\begin{tabular}{cc|ccc|ccc|ccc}
\hline Additive & {$\left[\mathrm{NaMoO}_{4}\right](\mu \mathrm{M})$} & \multicolumn{3}{c|}{$0 \mu \mathrm{M} \mathrm{H}_{2} \mathrm{O}_{2}$} & \multicolumn{3}{c|}{$10 \mu \mathrm{M} \mathrm{H}_{2} \mathrm{O}_{2}$} & \multicolumn{3}{c}{$100 \mu \mathrm{M} \mathrm{H}_{2} \mathrm{O}_{2}$} \\
\hline & 0 & 59,711 & 30,413 & 38,407 & 34,413 & 26,177 & 54,164 & 86,970 & 68,803 & 48,948 \\
& 1 & 36,829 & 38,478 & 40,456 & 27,103 & 23,437 & 25,142 & 74,322 & 79,262 & 64,673 \\
& 10 & 1,067 & 29,637 & 27,490 & 33,243 & 34,233 & 26,543 & 132,450 & 119,014 & 113,217 \\
& 100 & 24,734 & 26,617 & 17,702 & 38,768 & 55,874 & 53,722 & 476,166 & 482,448 & 468,686 \\
\hline $\mathrm{NaN}_{3}$ & 0 & 47,427 & 27,816 & 33,822 & 22,037 & 25,574 & 26,509 & 47,879 & 71,128 & 86,779 \\
$\mathrm{NaN}_{3}$ & 1 & 17,056 & 15,590 & 28,737 & 47,687 & 30,921 & 55,460 & 58,618 & 52,801 & 75,276 \\
$\mathrm{NaN}_{3}$ & 10 & 48,985 & 26,189 & 39,286 & 41,011 & 44,837 & 41,481 & 99,199 & 137,922 & 128,720 \\
$\mathrm{NaN}_{3}$ & 100 & 41,150 & 60,360 & 31,422 & 36,764 & 62,417 & 61,596 & 459,433 & 473,881 & 427,359 \\
\hline catalase & 0 & 47,781 & 25,839 & 97,988 & 24,872 & 37,852 & 55,740 & 24,774 & 36,194 & 57,786 \\
catalase & 1 & 32,277 & 18,911 & 88,941 & 25,228 & 47,957 & 62,449 & 34,302 & 31,904 & 54,776 \\
catalase & 10 & 30,189 & 24,960 & 82,044 & 31,421 & 39,031 & 88,171 & 39,161 & 54,221 & 66,499 \\
catalase & 100 & 27,512 & 34,883 & 69,835 & 25,678 & 32,090 & 94,073 & 103,725 & 102,097 & 137,047 \\
\hline
\end{tabular}

Table S6. Raw fluorescence values for determining selectivity of 1: Reaction with ${ }^{1} \mathrm{O}_{2}$. Data shown are the fluorescence at 40 min minus the fluorescence at $0 \min . n=3$.

\section{Determining selectivity of 1 : Reaction with $\cdot \mathrm{OH}$}

$\cdot \mathrm{OH}$ was generated through the reaction of $\mathrm{FeSO}_{4} \cdot 7 \mathrm{H}_{2} \mathrm{O}$ with $\mathrm{H}_{2} \mathrm{O}_{2}$. A solution of $100 \mu \mathrm{M} 1$ in ethanol $(20 \mu \mathrm{L})$ was added to $5: 95$ methanol $/ 50 \mathrm{mM}$ phosphate $\mathrm{pH} 7$ buffer $(140 \mu \mathrm{L})$. Water or $10^{4} \mathrm{U} / \mathrm{mL}$ catalase $(20 \mu \mathrm{L})$ was added to the mixture. $\mathrm{FeSO}_{4} \cdot 7 \mathrm{H}_{2} \mathrm{O}(27.4 \mathrm{mg})$ was added to ultrapure water $(2.00 \mathrm{~mL})$. This solution was diluted to $20 \mu \mathrm{M}, 200 \mu \mathrm{M}$, and $2.00 \mathrm{mM}$. $\mathrm{H}_{2} \mathrm{O}_{2}$ was diluted to $200 \mu \mathrm{M}$ and $2.00 \mathrm{mM}$. Equal volumes of $\mathrm{FeSO}_{4} \cdot 7 \mathrm{H}_{2} \mathrm{O}$ solution and $\mathrm{H}_{2} \mathrm{O}_{2}$ were added together, and an aliquot $(20 \mu \mathrm{L})$ was immediately transferred to the solution containing $\mathbf{1}$. The fluorescence intensity was measured immediately and again after incubation at $25^{\circ} \mathrm{C}$ for $40 \mathrm{~min}$.

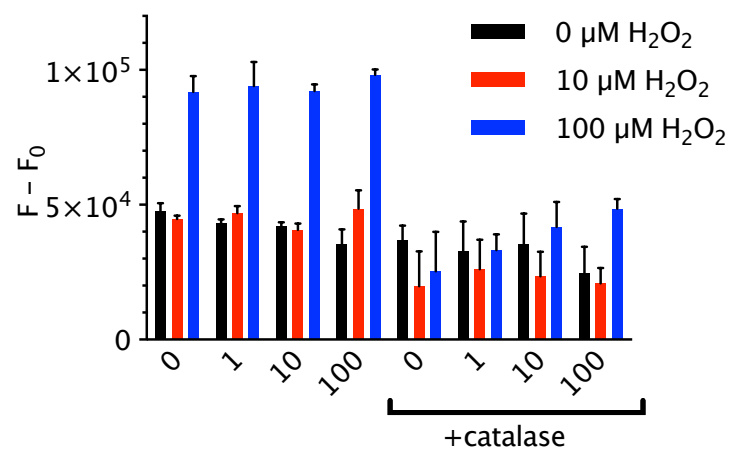

$\left[\mathrm{FeSO}_{4}\right](\mu \mathrm{M})$

Figure S9. Determining selectivity of 1: Reaction with $\cdot \mathrm{OH}$.

\begin{tabular}{cc|ccc|ccc|ccc}
\hline Additive & $\begin{array}{c}{[\mathrm{FeSO}} \\
(\mu \mathrm{M})\end{array}$ & \multicolumn{3}{|c|}{$0 \mu \mathrm{M} \mathrm{H}_{2} \mathrm{O}_{2}$} & \multicolumn{3}{c|}{$10 \mu \mathrm{M} \mathrm{H}_{2} \mathrm{O}_{2}$} & \multicolumn{3}{c}{$100 \mu \mathrm{M} \mathrm{H}_{2} \mathrm{O}_{2}$} \\
& 0 & 50,173 & 48,124 & 44,143 & 43,929 & 46,186 & 43,989 & 94,742 & 95,713 & 85,271 \\
& 1 & 44,775 & 42,847 & 41,775 & 49,425 & 47,262 & 44,251 & 103,905 & 91,684 & 86,594 \\
& 10 & 43,299 & 42,365 & 40,214 & 42,933 & 40,908 & 38,283 & 90,712 & 94,948 & 91,049 \\
& 100 & 32,709 & 41,651 & 31,615 & 56,260 & 46,281 & 43,358 & 99,391 & 95,778 & 99,384 \\
& 0 & 31,506 & 41,640 & 38,159 & 16,840 & 33,959 & 8,517 & 37,819 & 28,926 & 9,145 \\
catalase & 1 & 28,688 & 24,659 & 45,310 & 31,319 & 13,633 & 33,399 & 34,591 & 26,790 & 38,285 \\
catalase & 10 & 24,822 & 33,920 & 47,376 & 19,991 & 16,693 & 33,776 & 42,724 & 50,635 & 32,300 \\
catalase & 100 & 35,828 & 18,194 & 20,321 & 20,486 & 26,765 & 15,423 & 46,921 & 52,666 & 46,232 \\
catalase & 100
\end{tabular}

Table S7. Raw fluorescence values for determining selectivity of 1 : Reaction with $\bullet \mathrm{OH}$. Data shown are the fluorescence at 40 min minus the fluorescence at $0 \min . n=3$. 


\section{Determining selectivity of 1: Reaction with $\mathrm{CIO}^{-}$and $\mathrm{ONOO}^{-}$}

A solution of $0,1,10$, or $22 \mu \mathrm{M} \mathrm{ONOO}^{-}$in $0.3 \mathrm{M} \mathrm{NaOH}(20 \mu \mathrm{L})$ or $1,10,100$, or $1000 \mu \mathrm{M} \mathrm{NaOCl}$ in water $(20 \mu \mathrm{L})$ was added to the wells of a black 96-well plate. A solution of $10 \mu \mathrm{M} 1$ in DMSO (560 $\mu \mathrm{L})$ and 5:95 MeCN/1.2 M phosphate $\mathrm{pH} 7$ buffer $(4.48 \mathrm{~mL})$ was made; this solution $(180 \mu \mathrm{L})$ was transferred to each of the wells. The samples were allowed to incubate at $25{ }^{\circ} \mathrm{C}$ for $15 \mathrm{~min}$ before the fluorescence was measured.

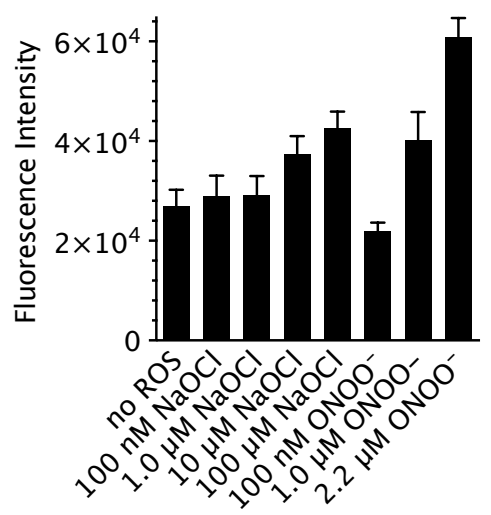

Figure S10. Determining selectivity of 1: Reaction with $\mathrm{ClO}^{-}$and ONOO-

\begin{tabular}{c|ccc}
\hline & \multicolumn{3}{|c}{ Fluorescence Intensity } \\
\hline no ROS & 30,591 & 24,478 & 26,025 \\
$100 \mathrm{nM} \mathrm{NaOCl}$ & 33,503 & 25,413 & 28,088 \\
$1.0 \mu \mathrm{M} \mathrm{NaOCl}$ & 28,551 & 25,590 & 33,211 \\
$10 \mu \mathrm{M} \mathrm{NaOCl}$ & 41,611 & 35,271 & 35,308 \\
$100 \mu \mathrm{M} \mathrm{NaOCl}$ & 46,362 & 40,070 & 41,695 \\
$100 \mathrm{nM} \mathrm{ONOO}-$ & 23,606 & 21,961 & 20,229 \\
$1.0 \mu \mathrm{M}$ ONOO- & 46,271 & 39,358 & 35,209 \\
$2.2 \mu \mathrm{M}$ ONOO-- & 63,954 & 56,351 & 61,987 \\
\hline
\end{tabular}

Table S8. Raw fluorescence values for determining selectivity of 1: Reaction with CIO- and ONOO- $n=3$.

\section{Determining selectivity of 1 : Reaction with ${ }^{\mathrm{t}} \mathrm{BuOOH}$}

A solution of 5:95 MeCN/50 mM phosphate $\mathrm{pH} 7$ buffer $(160 \mu \mathrm{L})$ was added to the wells of a black 96-well plate. 10 $\mu \mathrm{M} 1$ in DMSO $(20 \mu \mathrm{L})$ was added to each well. $0 \mathrm{mM} \mathrm{H}_{2} \mathrm{O}_{2}$ in water $(20 \mu \mathrm{L})$ or 0,10 , or $100 \mu \mathrm{M}{ }^{t} \mathrm{BuOOH}$ in DMSO $(20 \mu \mathrm{L})$ were then added to the wells. The samples were allowed to incubate at $25^{\circ} \mathrm{C}$ for $15 \mathrm{~min}$ before the fluorescence was measured.

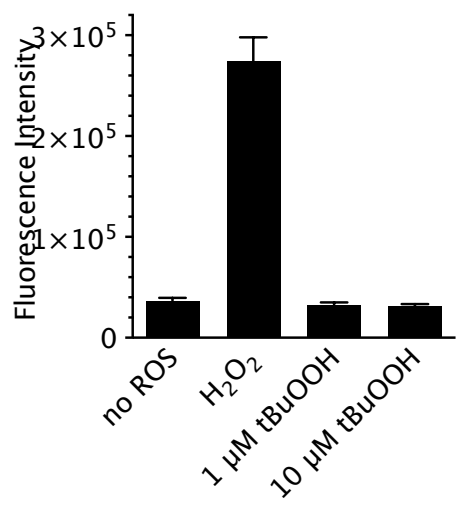

Figure S11. Determining selectivity of 1 : Reaction with ${ }^{\mathrm{t}} \mathrm{BuOOH}$ 


\begin{tabular}{c|rcr}
\hline & \multicolumn{3}{|c}{ Fluorescence Intensity } \\
\hline no ROS & 34,525 & 36,401 & 39,836 \\
$\mathrm{H}_{2} \mathrm{O}_{2}$ & 277,013 & 296,506 & 250,145 \\
$1 \mu \mathrm{M}{ }^{\mathrm{B}} \mathrm{BuOOH}$ & 32,951 & 29634 & 34,860 \\
$10 \mu \mathrm{M}{ }^{\mathrm{B}} \mathrm{BuOOH}$ & 31,650 & 28,922 & 33,363 \\
\hline
\end{tabular}

Table S9. Raw fluorescence values for Determining selectivity of 1: Reaction with ${ }^{\mathrm{t}} \mathrm{BuOOH} . n=3$.

\section{Determining selectivity of 1 : Reaction with $\mathrm{NO}_{2}{ }^{-}$}

$\mathrm{NaNO}_{2}(97.0 \mathrm{mg})$ was dissolved in ultrapure water $(2.00 \mathrm{~mL})$. This solution was diluted to $10 \mu \mathrm{M}, 100 \mu \mathrm{M}, 1.00 \mathrm{mM}$, and $10.0 \mathrm{mM} . \mathrm{H}_{2} \mathrm{O}_{2}$ was diluted to $10 \mu \mathrm{M}, 100 \mu \mathrm{M}, 1.00 \mathrm{mM}$, and $10.0 \mathrm{mM}$. A solution of $100 \mu \mathrm{M} 1$ in ethanol (20 $\mu \mathrm{L}$ ) was added to 5:95 methanol/50 mM phosphate $\mathrm{pH} 7$ buffer $(160 \mu \mathrm{L})$. The $\mathrm{NaNO}_{2}$ or $\mathrm{H}_{2} \mathrm{O}_{2}$ solutions $(20 \mu \mathrm{L})$ were added to the solution containing 1 and the fluorescence intensity was measured immediately and again after incubation at $25^{\circ} \mathrm{C}$ for $15 \mathrm{~min}$.

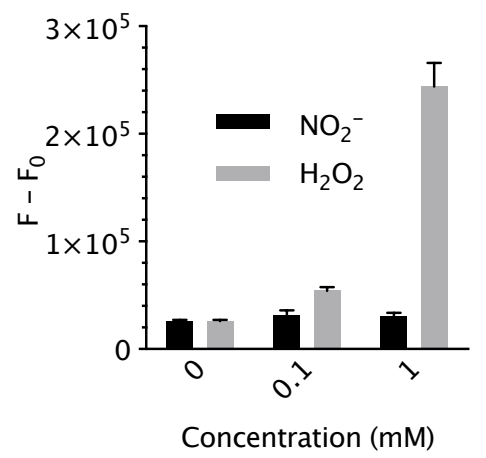

Figure S12. Determining selectivity of 1 : Reaction with $\mathrm{NO}_{2}^{-} . n=3$.

\begin{tabular}{c|rrr|rrr}
\hline $\begin{array}{c}{\left[\mathrm{NO}_{2}{ }^{-}\right] \text {or }\left[\mathrm{H}_{2} \mathrm{O}_{2}\right]} \\
(\mu \mathrm{M})\end{array}$ & \multicolumn{2}{|c|}{$\mathrm{NO}_{2}^{-}$} & & \multicolumn{2}{c}{$\mathrm{H}_{2} \mathrm{O}_{2}$} \\
\hline 0 & 24,359 & 26,870 & 26,226 & & & \\
0.1 & 31,075 & 36,429 & 27,504 & 58,172 & 52,104 & 52,249 \\
1 & 26,768 & 31,470 & 33,004 & 266,770 & 242,313 & 222,834 \\
\hline
\end{tabular}

Table S10. Raw fluorescence values for determining selectivity of 1: Reaction with $\mathrm{NO}_{2}^{-}$. Data shown are the fluorescence at 15 min minus the fluorescence at $0 \min . n=3$.

\section{Determining selectivity of 1 : Reaction with $\mathrm{NO}_{3}{ }^{-}$}

$\mathrm{NaNO}_{3}(30.9 \mathrm{mg})$ was dissolved in ultrapure water $(2.00 \mathrm{~mL})$. This solution was diluted to $10 \mu \mathrm{M}, 100 \mu \mathrm{M}, 1.00 \mathrm{mM}$, and $10.0 \mathrm{mM} . \mathrm{H}_{2} \mathrm{O}_{2}$ was diluted to $10 \mu \mathrm{M}, 100 \mu \mathrm{M}, 1.00 \mathrm{mM}$, and $10.0 \mathrm{mM}$. A solution of $100 \mu \mathrm{M} 1$ in ethanol (20 $\mu \mathrm{L})$ was added to 5:95 methanol/50 mM pH 7 potassium phosphate buffer $(160 \mu \mathrm{L})$. The $\mathrm{NaNO}_{3}$ or $\mathrm{H}_{2} \mathrm{O}_{2}$ solutions $(20$ $\mu \mathrm{L}$ ) were added to the solution containing $\mathbf{1}$ and the fluorescence intensity was measured immediately and again after incubation at $25^{\circ} \mathrm{C}$ for $15 \mathrm{~min}$. 


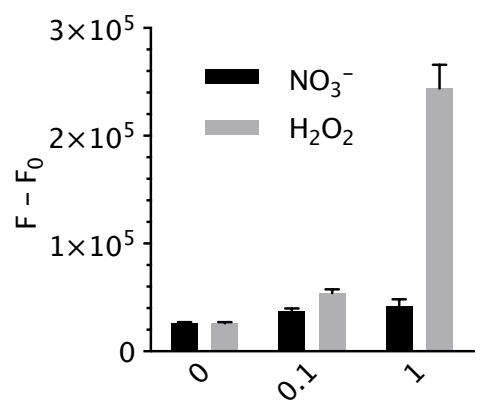

Concentration $(\mathrm{mM})$

Figure S13. Determining selectivity of 1: Reaction with $\mathrm{NO}_{3}^{-} \cdot n=3$.

\begin{tabular}{c|rrr|rrr}
\hline$\left[\mathrm{NO}_{3}{ }^{-}\right]$or $\left[\mathrm{H}_{2} \mathrm{O}_{2}\right](\mu \mathrm{M})$ & \multicolumn{3}{|c|}{$\mathrm{NO}_{3}^{-}$} & \multicolumn{3}{|c}{$\mathrm{H}_{2} \mathrm{O}_{2}$} \\
\hline 0 & 24,359 & 26,870 & 26,226 & & & \\
0.1 & 34,507 & 35,439 & 40,487 & 58,172 & 52,104 & 52,249 \\
1 & 43,966 & 35,385 & 47,433 & 266,770 & 242,313 & 222,834 \\
\hline
\end{tabular}

Table S11. Raw fluorescence values for determining selectivity of 1: Reaction with $\mathrm{NO}_{3}-$. Data shown are the fluorescence at 15 min minus the fluorescence at $0 \min . n=3$.

\section{Determining selectivity of 1: Reaction with NO•}

A NO solution was generated by the addition of $\mathrm{H}_{2} \mathrm{SO}_{4}$ to $\mathrm{NaNO}_{2}$. A round-bottom flask containing a saturated solution of $\mathrm{NaNO}_{2}$ was connected to a series of three bubblers and one Erlenmeyer flask; the first two bubblers contained $30 \%$ $\mathrm{NaOH}$, and the third contained ultrapure water. The flask contained ultrapure water $(10 \mathrm{~mL})$. The solutions were degassed with argon for $30 \mathrm{~min}$. Then a $2 \mathrm{M}$ solution of $\mathrm{H}_{2} \mathrm{SO}_{4}(1 \mathrm{~mL})$ was added to the saturated $\mathrm{NaNO}_{2}$ to produce a $1.8 \mathrm{mM}$ solution of $\mathrm{NO} \cdot$ (assuming saturation at $\left.25^{\circ} \mathrm{C}\right)$ in the flask. A solution of $10 \mu \mathrm{M} 1$ in DMSO $(20 \mu \mathrm{L})$ was added to 5:95 acetonitrile $/ 50 \mathrm{mM} \mathrm{pH} 7$ potassium phosphate buffer $(160 \mu \mathrm{L})$. The NO・ solution $(20 \mu \mathrm{L})$ was then added to the mixture containing 1 . The fluorescence was measured immediately and again after $15 \mathrm{~min}$ at $25^{\circ} \mathrm{C}$.

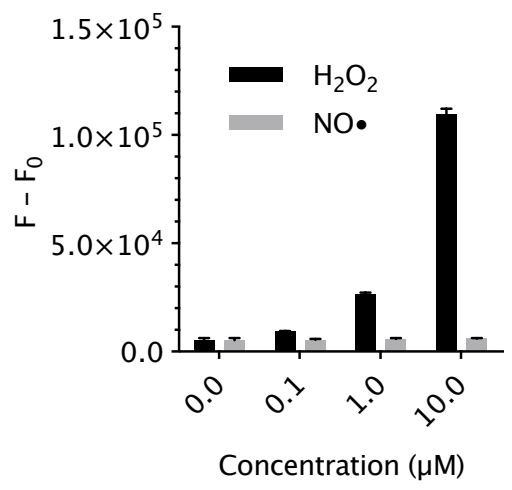

Figure S14. Determining selectivity of 1 : Reaction with NO $. n=3$.

\begin{tabular}{c|rrr|rrr}
\hline$[\mathrm{NO} \cdot]$ or $\left[\mathrm{H}_{2} \mathrm{O}_{2}\right](\mu \mathrm{M})$ & \multicolumn{3}{|c|}{$\mathrm{NO}$} & \multicolumn{3}{c}{$\mathrm{H}_{2} \mathrm{O}_{2}$} \\
\hline 0 & 4,567 & 5,018 & 6,300 & & \\
0.1 & 5,344 & 5,827 & 5,393 & 9,370 & 9,525 & 9,517 \\
1 & 6,268 & 5,961 & 5,430 & 26,155 & 26,618 & 27,176 \\
10 & 6,104 & 6,207 & 5,735 & 111,008 & 106,765 & 111,053 \\
\hline
\end{tabular}

Table S12. Raw fluorescence values for Determining selectivity of 1: Reaction with NO•. Data shown are the fluorescence at 15 min minus the fluorescence at $0 \min . n=3$. 


\section{$\mathrm{pH}$ dependence of the reaction of 1 with $\mathrm{H}_{2} \mathrm{O}_{2}$}

A solution of $50 \mathrm{mM}$ phosphate $\mathrm{pH} 7.3$ buffer was treated with $1.0 \mathrm{~N} \mathrm{HCl}$ to adjust the $\mathrm{pH}$ to $7.0,6.5,5.9,5.4,4.5$, or 4.1. The concentration of the resulting buffers was adjusted with water to $25 \mathrm{mM}$ phosphate buffer. Solutions of 25 $\mathrm{mM}$ phosphate $\mathrm{pH} 7.3,7.0,6.5,5.9,5.4,4.5$, or 4.1 buffer $(160 \mu \mathrm{L})$ and $100 \mu \mathrm{M}$ probe 1 in $\mathrm{MeOH}$ were treated with $100 \mu \mathrm{M}, 10 \mu \mathrm{M}$ or $0 \mu \mathrm{M} \mathrm{H}_{2} \mathrm{O}_{2}$ in water. The solutions were allowed to incubate at $23{ }^{\circ} \mathrm{C}$ for $20 \mathrm{~min}$ prior to measuring the fluorescence.

\begin{tabular}{c|rrr|rrr|rrr}
\hline $\mathrm{pH}$ & \multicolumn{3}{|c}{$10 \mu \mathrm{M} \mathrm{H}_{2} \mathrm{O}_{2}$} & & \multicolumn{3}{c|}{$1 \mu \mathrm{M} \mathrm{H}_{2} \mathrm{O}_{2}$} & \multicolumn{3}{c}{$0 \mu \mathrm{M} \mathrm{H} \mathrm{O}_{2}$} \\
\hline 7.30 & 372,555 & 388,584 & 401,912 & 228,368 & 208,913 & 186,665 & 189,898 & 183,424 & 169,054 \\
7.00 & 389,464 & 369,467 & 390,006 & 247,464 & 221,499 & 229,530 & 199,101 & 207,136 & 187,676 \\
6.50 & 332,896 & 341,948 & 335,544 & 203,661 & 188,050 & 184,986 & 155,151 & 183,747 & 149,421 \\
5.90 & 167,836 & 187,633 & 154,515 & 113,703 & 111,368 & 107,545 & 87,499 & 89,708 & 90,424 \\
5.40 & 103,516 & 107,311 & 103,354 & 61,365 & 63,294 & 60,943 & 56,192 & 56,334 & 52,671 \\
4.50 & 55,577 & 54,961 & 56,315 & 40,599 & 31,790 & 33,283 & 29,770 & 29,064 & 29,069 \\
4.10 & 51,632 & 54,097 & 52,472 & 35,884 & 30,492 & 30,471 & 28,470 & 29,037 & 28,661 \\
\hline
\end{tabular}

Table S13. Raw fluorescence intensities for the reaction of 1 with $\mathrm{H}_{2} \mathrm{O}_{2}$ at $\mathrm{pH} 4.1-7.3$.

\section{pH dependence of phenol 5}

Phenol 5 was dissolved in water to a concentration of $100 \mathrm{nM}$. This solution $(100 \mathrm{~mL})$ was titrated with $\mathrm{HCl}$ and $\mathrm{NaOH}$. The $\mathrm{pH}$ was measured after each addition before measuring the fluorescence using a Horiba FluoroMax3 fluorescence spectrometer. Fluorescence was measured using $1 \mathrm{~nm}$ slit widths with an excitation wavelength of $496 \mathrm{~nm}$ and an emission wavelength of $510 \mathrm{~nm}$.

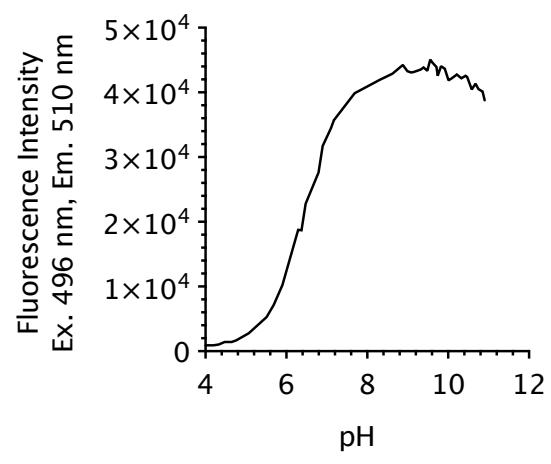

Figure $\mathbf{S} 15$. The $\mathrm{pH}$ dependence of phenol $\mathbf{5}$. 


\begin{tabular}{|c|c|}
\hline $\mathrm{pH}$ & Fluorescence Intensity \\
\hline 3.99 & 920 \\
\hline 4.20 & 930 \\
\hline 4.33 & 1,070 \\
\hline 4.48 & 1,450 \\
\hline 4.65 & 1,440 \\
\hline 4.77 & 1,670 \\
\hline 5.07 & 2,790 \\
\hline 5.51 & 5,280 \\
\hline 5.69 & 7,130 \\
\hline 5.90 & 10,250 \\
\hline 6.30 & 18,790 \\
\hline 6.38 & 18,720 \\
\hline 6.48 & 22,820 \\
\hline 6.80 & 27,620 \\
\hline 6.90 & 31,730 \\
\hline 7.11 & 34,510 \\
\hline 7.18 & 35,740 \\
\hline 7.69 & 39,880 \\
\hline 8.31 & 41,950 \\
\hline 8.63 & 42,930 \\
\hline 8.88 & 44,240 \\
\hline 9.00 & 43,280 \\
\hline 9.09 & 43,110 \\
\hline 9.15 & 43,140 \\
\hline 9.32 & 43,550 \\
\hline 9.40 & 43,850 \\
\hline 9.49 & 43,340 \\
\hline 9.56 & 45,080 \\
\hline 9.61 & 44,640 \\
\hline 9.71 & 43,930 \\
\hline 9.75 & 42,610 \\
\hline 9.83 & 44,070 \\
\hline 9.92 & 43,670 \\
\hline 10.01 & 41,900 \\
\hline 10.10 & 42,170 \\
\hline 10.22 & 42,800 \\
\hline 10.33 & 42,170 \\
\hline 10.43 & 42,570 \\
\hline 10.48 & 42,410 \\
\hline 10.59 & 40,450 \\
\hline 10.68 & 41,370 \\
\hline 10.75 & 40,520 \\
\hline 10.85 & 40,140 \\
\hline 10.91 & 38,790 \\
\hline
\end{tabular}

Table S14. Raw fluorescence values for the $\mathrm{pH}$ dependence of hydroxymethyl Tokyo Green. 


\section{Cellular Imaging}

Cells were seeded on 35-mm glass bottom dishes (MatTek Corporation, Ashland, MA) and incubated with $0.5 \mu \mathrm{M} 1$ in $0.1 \%$ DMSO in DMEM (10\% FBS with penicillin/streptomycin) for 15 min prior to imaging. In some cases, cells were incubated with $1 \mu \mathrm{M}$ MitoTracker ${ }^{\circledR}$ Red FM (ThermoFisher Scientific) for $20 \mathrm{~min}$ at $37{ }^{\circ} \mathrm{C}$. The treated cells were washed with HBSS, and the media was replaced with HBSS $(2.00 \mathrm{~mL})$. The dish was inserted in a closed, thermocontrolled $\left(37^{\circ} \mathrm{C}\right)$ stage top incubator (Tokai Hit Co., Shizuoka-ken, Japan) atop the motorized stage of an inverted Nikon TiE fluorescent microscope (Nikon Inc., Melville, NY) equipped with a 60X oil immersion optic (Nikon, CFI PlanFluor, NA 1.49) and NIS Elements Software. The sample was excited using the $470 \mathrm{~nm}$ line of a Lumencor diodepumped light engine (SpectraX, Lumencor Inc., Beaverton OR). Fluorescence was detected using an ET-GFP filter set (Chroma Technology Corp) and ORCA-Flash 4.0 sCMOS camera (HAMAMATSU Corporation, Bridgewater, NJ). MitoTracker Red was excited using the $555 \mathrm{~nm}$ line and detected using a TRITC filter set. Data were collected every 30 s over a 10 -min period.

a

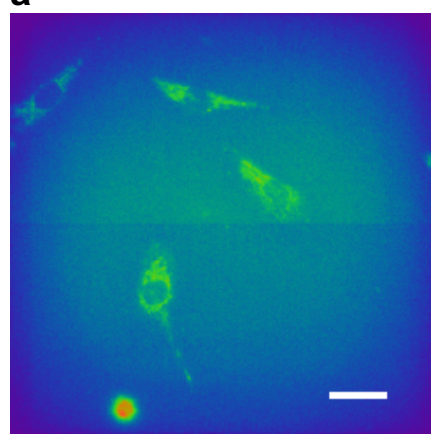

b

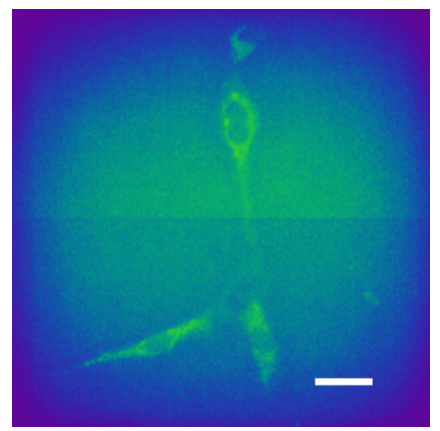

Figure S16. Pseudo-color image of RAW cells loaded with $5 \mu \mathrm{M}$ dihydrodichorofluorescein diacetate. (a) Without stimulation by ionomycin. (b) With stimulation by ionomycin. The scale bars are $20 \mu \mathrm{m}$.

\section{Zebrafish tail-wounding model}

Three-day post-fertilization zebrafish embryos were removed from their chorion and allowed to swim in $1 \mathrm{mM} 1$ for 2 $\mathrm{h}(0.1 \% \mathrm{v} / \mathrm{v}$ DMSO), leading to effective dye loading. Following this, the fish were anesthetized and mounted in agar. The tail fins were clipped with a razor blade. Fluorescence images were obtained every $60 \mathrm{~s}$ for $60 \mathrm{~min}$ using an inverted Nikon TiE fluorescent microscope (Nikon Inc., Melville, NY) equipped with a 20X 0.75 NA lens and NIS Elements Software. The sample was excited using the $470 \mathrm{~nm}$ line of a Lumencor diode-pumped light engine (SpectraX, Lumencor Inc., Beaverton OR), and the fluorescence signals were detected using an ET-GFP filter set (Chroma Technology Corp) and ORCA-Flash 4.0 sCMOS camera (HAMAMATSU Corporation, Bridgewater, NJ).

\section{References}

1. L. Ying; B. P. Bruce; Bioconj. Chem., 2011, 22, 987-992.

2. S. Ando, K. Koide; J. Am. Chem. Soc. 2011, 133, 2556-2566.

3. A. Krief, F. Lonez; Tetrahedron Lett. 2002, 35, 6255-6257.

\section{Author Contributions}

K.K. conceived the project and designed the probe. U.B. and I.P. synthesized the probe (Figure 2). I. P. performed the mechanistic studies (Figure 3) and pH dependence study (Figure 5c). U. B. performed kinetic studies (Figure 4). D.P. performed the experiments described in Figure 5a and Figure 5b. D.P., C.M.C., and S.C.W. performed the experiments described in Figures 6 and 7. D.P., I.P., and K.K. wrote the manuscript. 

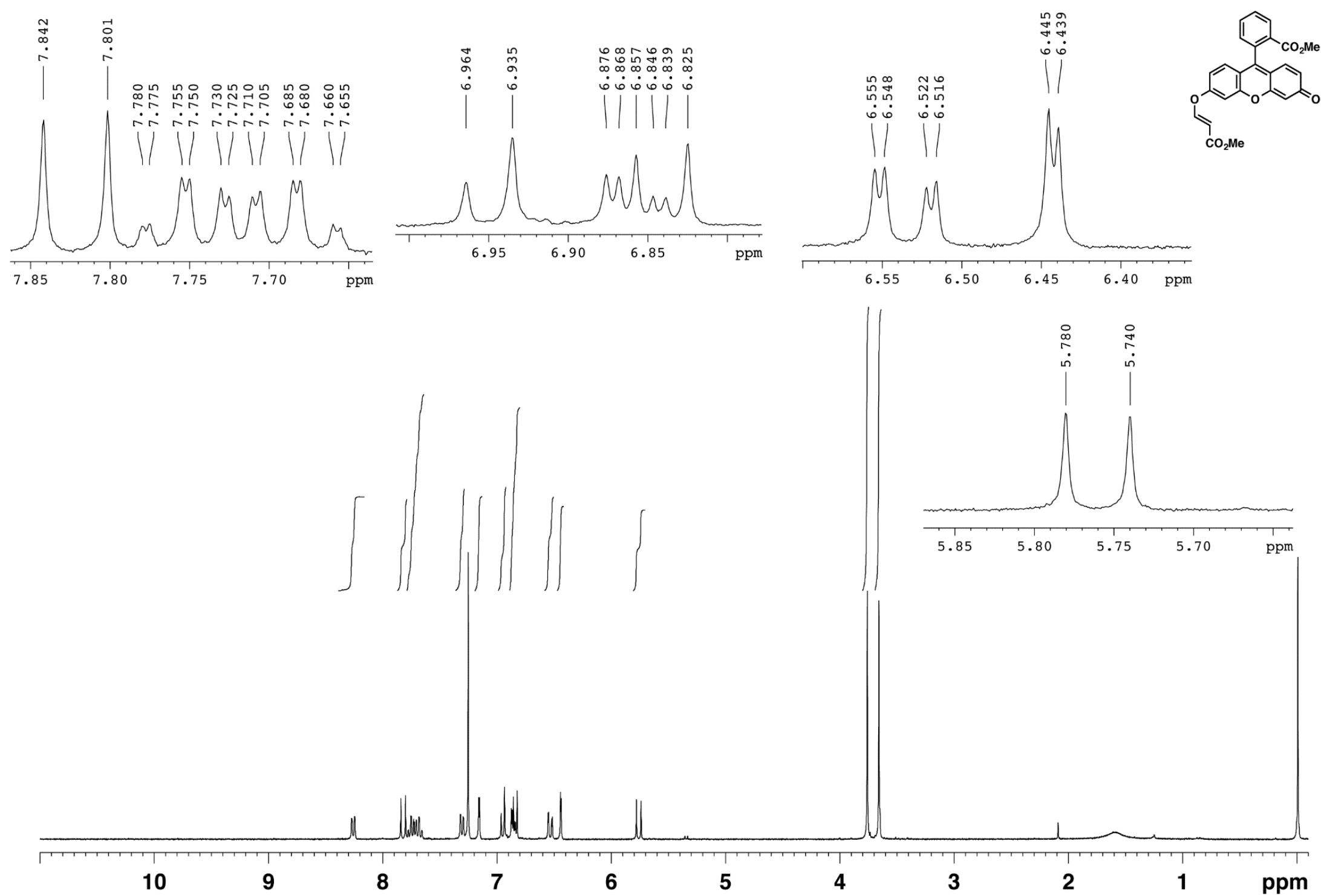

Spectrum 1. ${ }^{1} \mathrm{H}$ NMR spectrum of $8\left(300 \mathrm{MHz}, \mathrm{CDCl}_{3}, 293 \mathrm{~K}\right)$. 


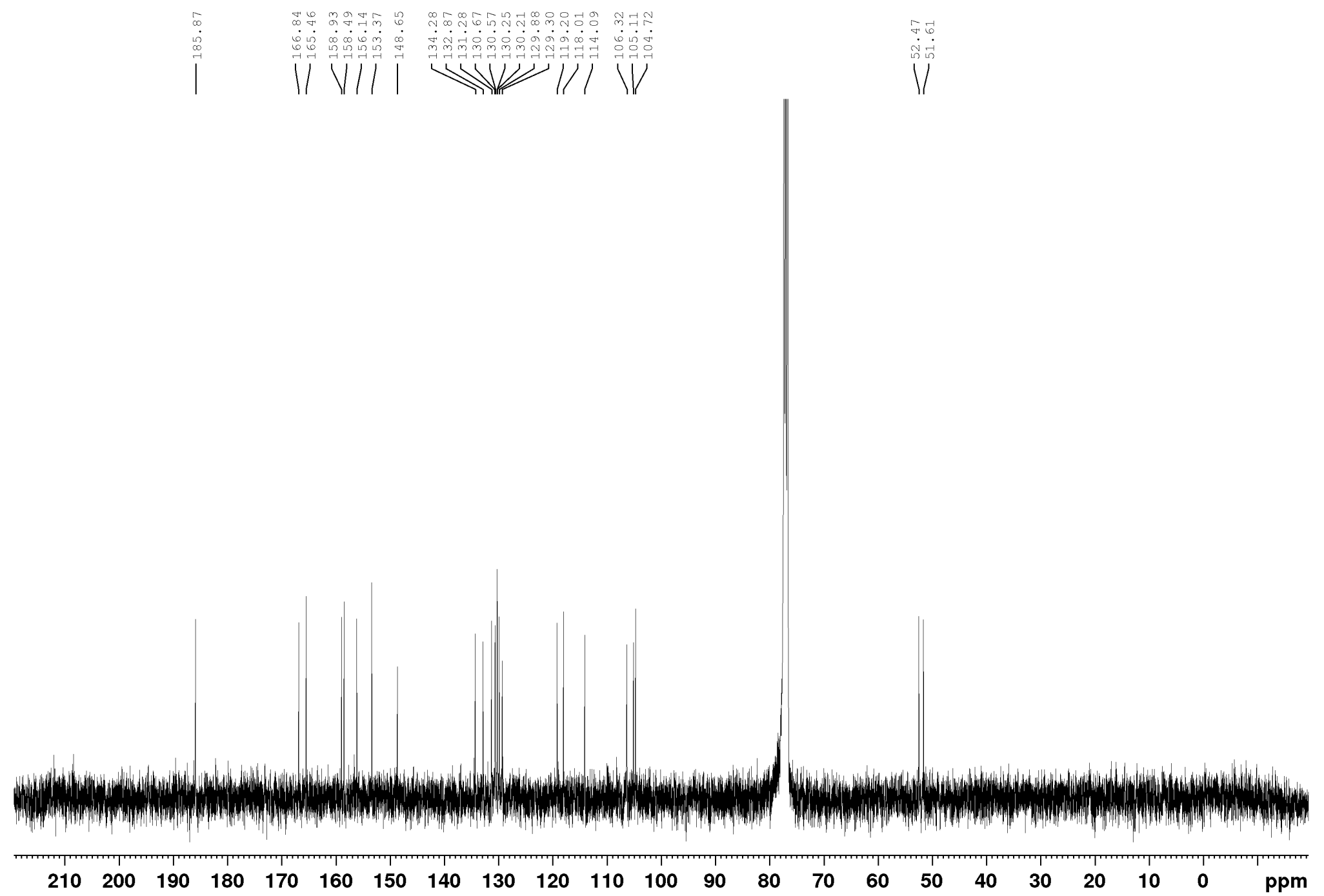

Spectrum 2. ${ }^{13} \mathrm{C}$ NMR spectrum of $8\left(100 \mathrm{MHz}, \mathrm{CDCl}_{3}, 293 \mathrm{~K}\right)$ 

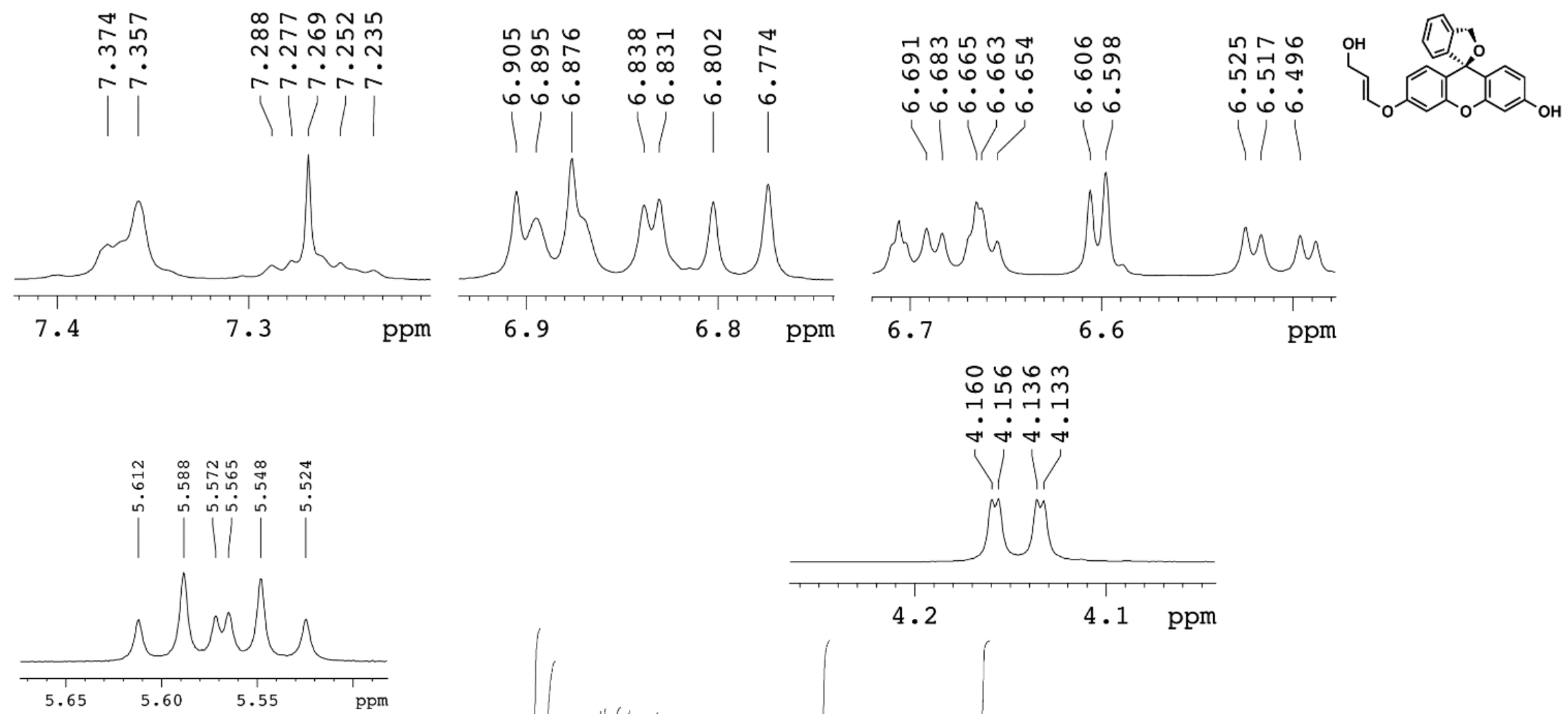

웅ํำ

ㄱ.
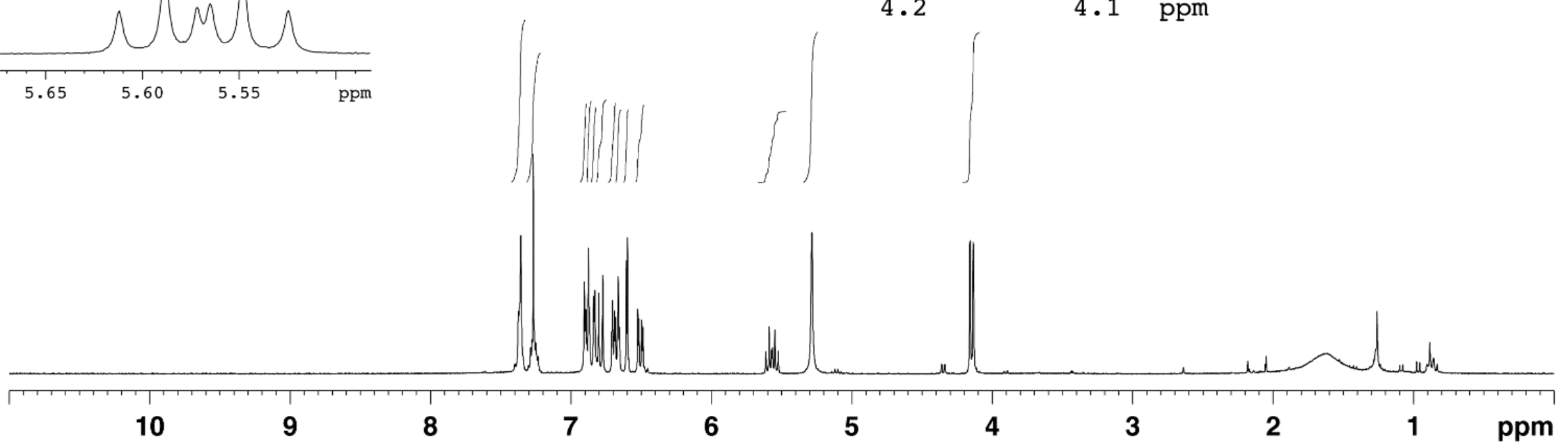

Spectrum 3. ${ }^{1} \mathrm{H}$ NMR spectrum of $9\left(300 \mathrm{MHz}, \mathrm{CDCl}_{3}, 293 \mathrm{~K}\right)$. 


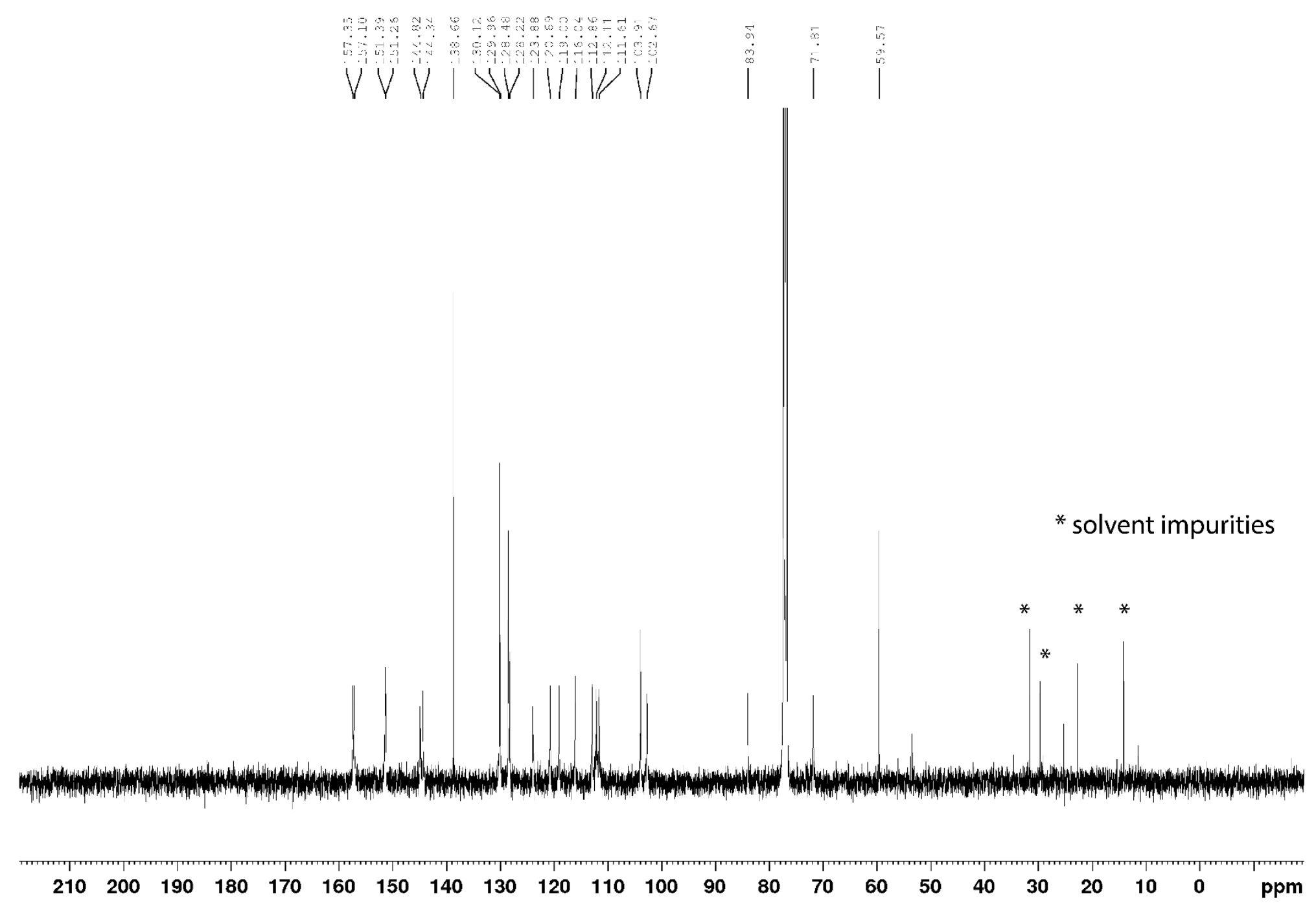

Spectrum 4. ${ }^{13} \mathrm{C}$ NMR spectrum of $9\left(100 \mathrm{MHz}, \mathrm{CDCl}_{3}, 293 \mathrm{~K}\right)$ 


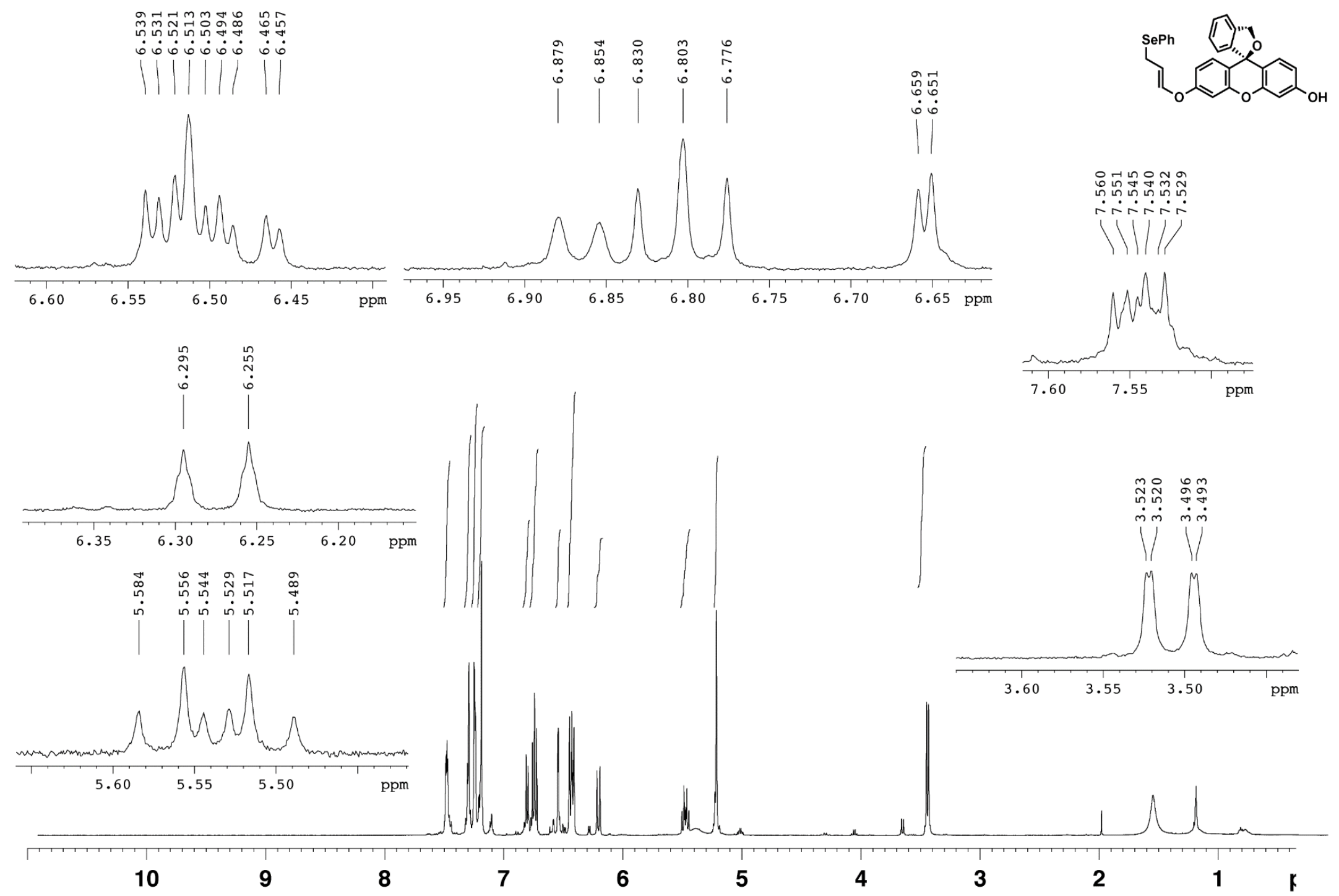

Spectrum 5. ${ }^{1} \mathrm{H}$ NMR spectrum of 1 (300 MHz, $\left.\mathrm{CDCl}_{3}, 293 \mathrm{~K}\right)$. 


$$
=
$$

